\title{
Excavation of a Neolithic enclosure and an Iron Age settlement at Douglasmuir, Angus
}

\section{Jill Kendrick*}

\author{
with contributions by Gordon J Barclay, Trevor G Cowie \& \\ Alan Saville, and illustrations by Jill Kendrick, Angela Townshend \& \\ Alan Braby
}

\begin{abstract}
The complete excavation of a post-defined Neolithic enclosure took place in 1979 and 1980 in advance of the construction of a gas compressor station for the British Gas Corporation. The enclosure appeared to have been constructed in two parts. There was little evidence for any associated activity except for a pit in the north half. Three charcoal samples from the post-holes produced radiocarbon dates in the range 3930-3390 cal BC. A small sample of a scatter of pits visible on aerial photographs was also excavated.

Six penannular ring-ditch houses dating to the mid first millennium $B C$ were also investigated. The houses were of the broad ring-ditch type with internal ring beam support. Other features included six-post structures and crescent-shaped hollows which might be the truncated remains of further house sites. There was little horizontal stratigraphy.

The project was arranged and funded by Historic Scotland and its predecessor departments, with a contribution by British Gas.
\end{abstract}

\section{INTRODUCTION}

Douglasmuir (illus 1) lies about $8 \mathrm{~km}$ north of Arbroath, near the village of Friockheim in the valley of the Lunan Water (NGR NO 617481). The site was chosen by the British Gas Corporation for the construction of a gas compressor station forming part of the St Fergus to Bishop Auckland gas pipeline.

The Lunan Water and its tributaries flow through a deposit of fluvio-glacial sand and gravel which overlies the Lower Old Red Sandstone of the Midland Valley. This fertile land is today mainly in arable agriculture, with some soft fruit production and dairy farming. The well-drained subsoil and extensive cereal cultivation combine to allow the recognition of many cropmark sites (RCAHMS 1978).

The Douglasmuir sites were not subject to modern ploughing until the $1950 \mathrm{~s}$, prior to which they lay in an area of rough ground with bushes and small trees (1st edn Ordnance Survey 6-inch 

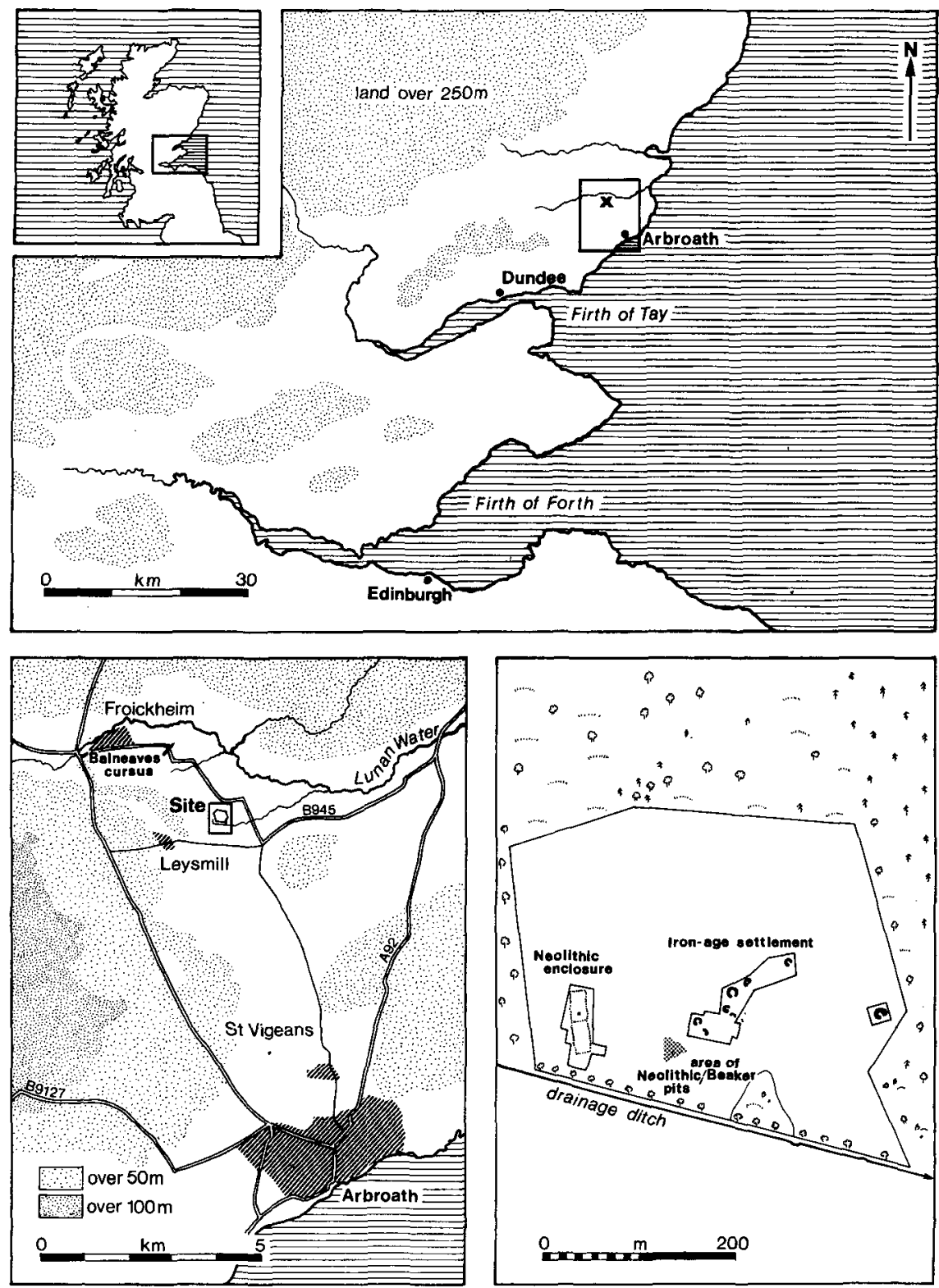

ILLus 1 Location map (Based on the Ordnance Survey map @ Crown copyright)

map, Forfarshire sheet XL, surveyed 1859-61, published 1865). According to the landowner, the land showed distinct ridge and furrow before ploughing. The cropmark of the Neolithic site (Douglasmuir site B) has been recorded only once, by Cambridge University Committee for Aerial Photography aerial survey on 1 August 1970, together with the nearby Iron Age houses (Douglasmuir site A). The proposed development of the site provided the opportunity for what was to be the first major excavation in this archaeologically important valley. 


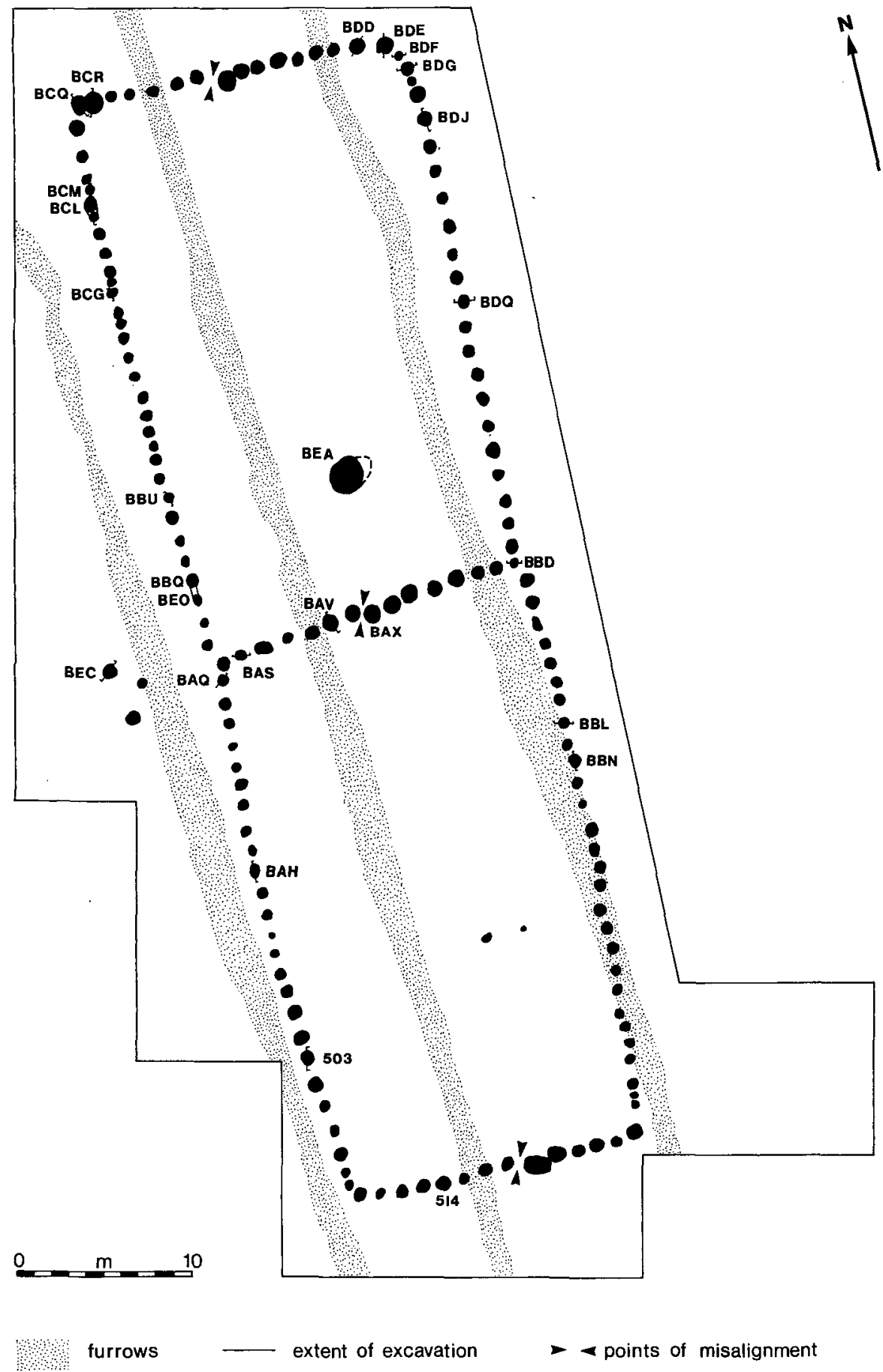

ILLus 2 Site plan of the Neolithic enclosure 
The excavation of the two sites took place in August and September 1979, and from March to May 1980 (Kendrick 1980, 1982). Construction of the compressor station started in July 1980 and a watching brief was undertaken to investigate further pits found then (site F). The 1979 season was financed by what was then the Ancient Monuments Branch of the Scottish Development Department. The 1980 season and some of the post-excavation work was generously sponsored by the British Gas Corporation. The remainder of the post-excavation work has been funded by SDD (Ancient Monuments) and its successor body, Historic Scotland. Historic Scotland regrets the delay between submission of a first draft of the report in 1985, and the submission of the publication draft in 1994; this problem was caused by delays in editorial work commissioned and managed by Historic Scotland, largely outwith the control of the author.

\section{THE NEOLITHIC ENCLOSURE}

\section{THE EXCAVATION}

In the first season the southern half of the enclosure was stripped of topsoil and the features excavated. The rest of the enclosure was excavated in the second season (illus $2 \& 3$ ).

The subsoil was a coarse fluvio-glacial gravel, banded occasionally with sand. Its surface was scored with grooves resulting from modern deep ploughing. Three broad but shallow ridges, thought to be the remains of broad rig cultivation, crossed the site from north to south, on a slightly different alignment from the enclosure. The furrows between the broad ridges were filled with a contemporary ploughsoil to a maximum depth of $0.1 \mathrm{~m}$ below the normal topsoil depth; in some places this obscured the features of the enclosure.

The post-holes were excavated in a variety of ways, to extract the maximum amount of information in the short time available. Half sectioning was found to be the most effective when combined with careful removal of each half in shallow spits, recording the reduced plan when necessary. The complete section was then drawn and the other half removed in the same way. The fills of some post-holes were removed completely in plan, providing plan views of post-pipe and packing. Others were sectioned at $0.1 \mathrm{~m}$ intervals using box sections.

\section{THE ENCLOSURE}

The post-hole delineated enclosure was aligned north/south and measured approximately $65 \mathrm{~m}$ by $20 \mathrm{~m}$ with an internal division transversely bisecting it. The distribution of the post-holes was not regular and the enclosure was not strictly rectangular (illus $2 \& 3$ ). The post-holes varied in size from $0.5 \mathrm{~m}$ to $1 \mathrm{~m}$ in diameter and had a maximum depth of $0.6 \mathrm{~m}$ (illus 4). Three shallow pits to the west of the enclosure, two small post-holes in the south part and a large pit in the north part were the only other features.

The ends of the enclosure and the transverse division were composed of substantial, deep postholes, whilst the post-holes of the sides were generally smaller. The west side north of the division was made up of 30 small, closely spaced post-holes, compared with 20 larger holes on the east side. The west side south of the division was made up of 25 fairly evenly spaced post-holes, whilst the other side had 28 less regularly spaced holes of decreasing diameter towards the south. The west side of the south part of the enclosure was markedly bowed. Only two post-holes had any form of linking feature: BBQ and BEO (illus 2).

The timbers in the majority of the post-holes could be detected as a dark stain in the base of the fill, or as a clearly visible post-pipe of dark loamy soil (illus 4). There was no convincing evidence of post replacement at Douglasmuir. In all cases, including post-holes dug into sand, the packing was redeposited gravel, which often differed from the subsoil only in that it was slightly looser.

Certain posts appeared to have been burnt in situ and the identification by Dr C Keepax of the charcoal 


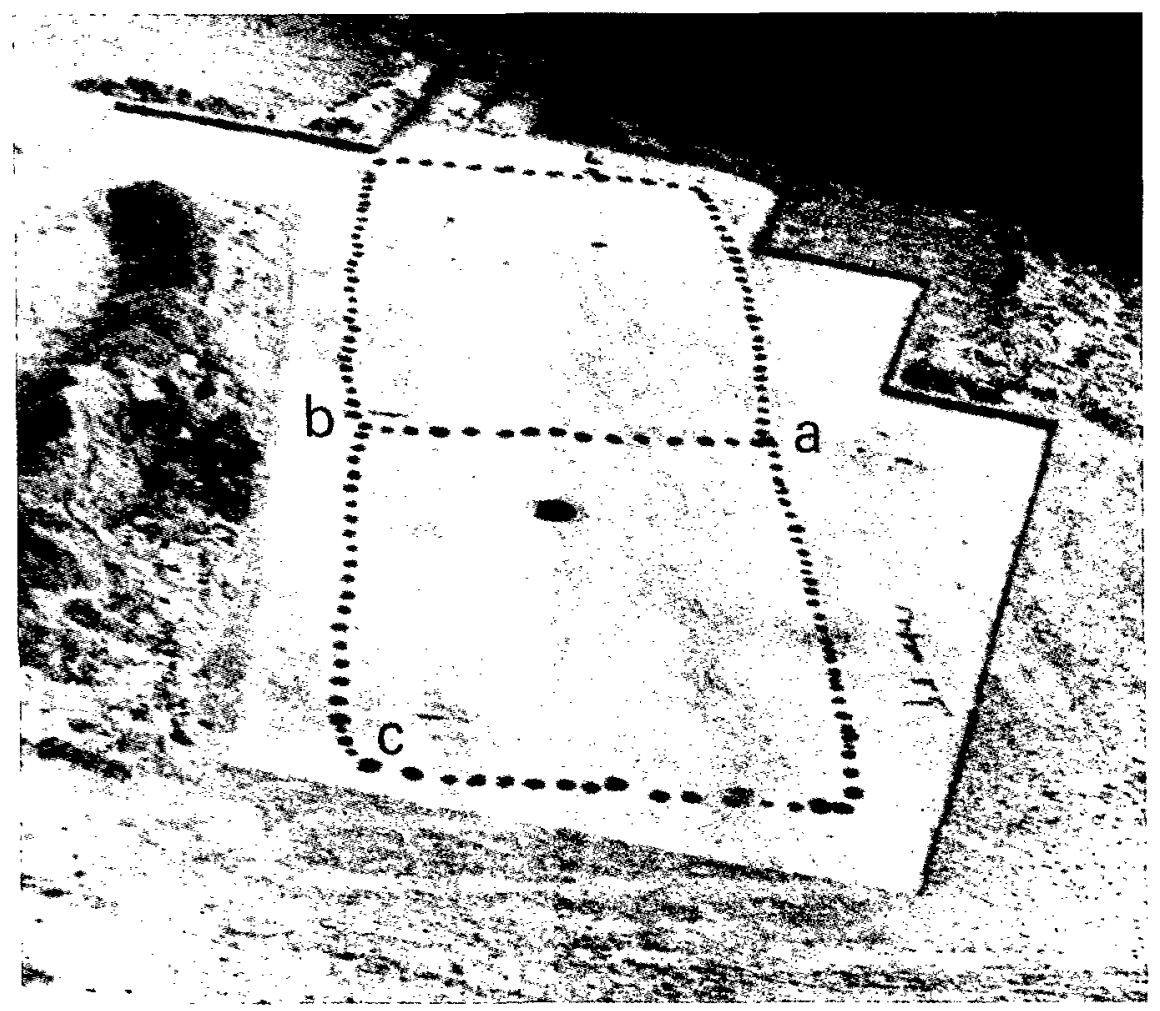

Illus 3 The Neolithic enclosure during excavation, from the north (Copyright: Cambridge University Committee for Aerial Photography)

from three post-holes (numbers F514, BDD \& BAU, marked on illus 2) from a single species (mature oak), would support this observation. Three radiocarbon dates were obtained, using these three samples. The radiocarbon determinations were undertaken at Glasgow University. The calibrations were undertaken using the Radiocarbon Calibration Program (version 3.03) of the Quaternary Research Center of the University of Washington (Stuiver \& Reimer 1993; Stuiver \& Becker 1993).

There were no artefactual remains from the post-holes.

\section{THE PITS}

A large pit occupied a prominent position in the southern part of the north portion of the enclosure (marked BEA on illus 5). The upper fill was of a dark brown/black, fairly soft loam. The remainder, and by far the greater part of the fill, consisted of layers of loam, loamy gravel, sand and stones, sloping from the sides to

\section{TABLE 1}

Lab. No.

Raw date

C13 adj.

Context

Calibrated Date BC (2 sigma)

GU-1210

$4855+55$ bp

$-24.8 \%$

GU-1469

$4895+70 \mathrm{bp}$

$-24.6 \%$

GU-1470

$4900+65 b p$

$-25.2 \%$

F514 - post-pipe

$\mathrm{BDD}$ - charcoal from throughout post-hole

BAU
$3760-3390$

$3930-3390$

$3930-3510$ 

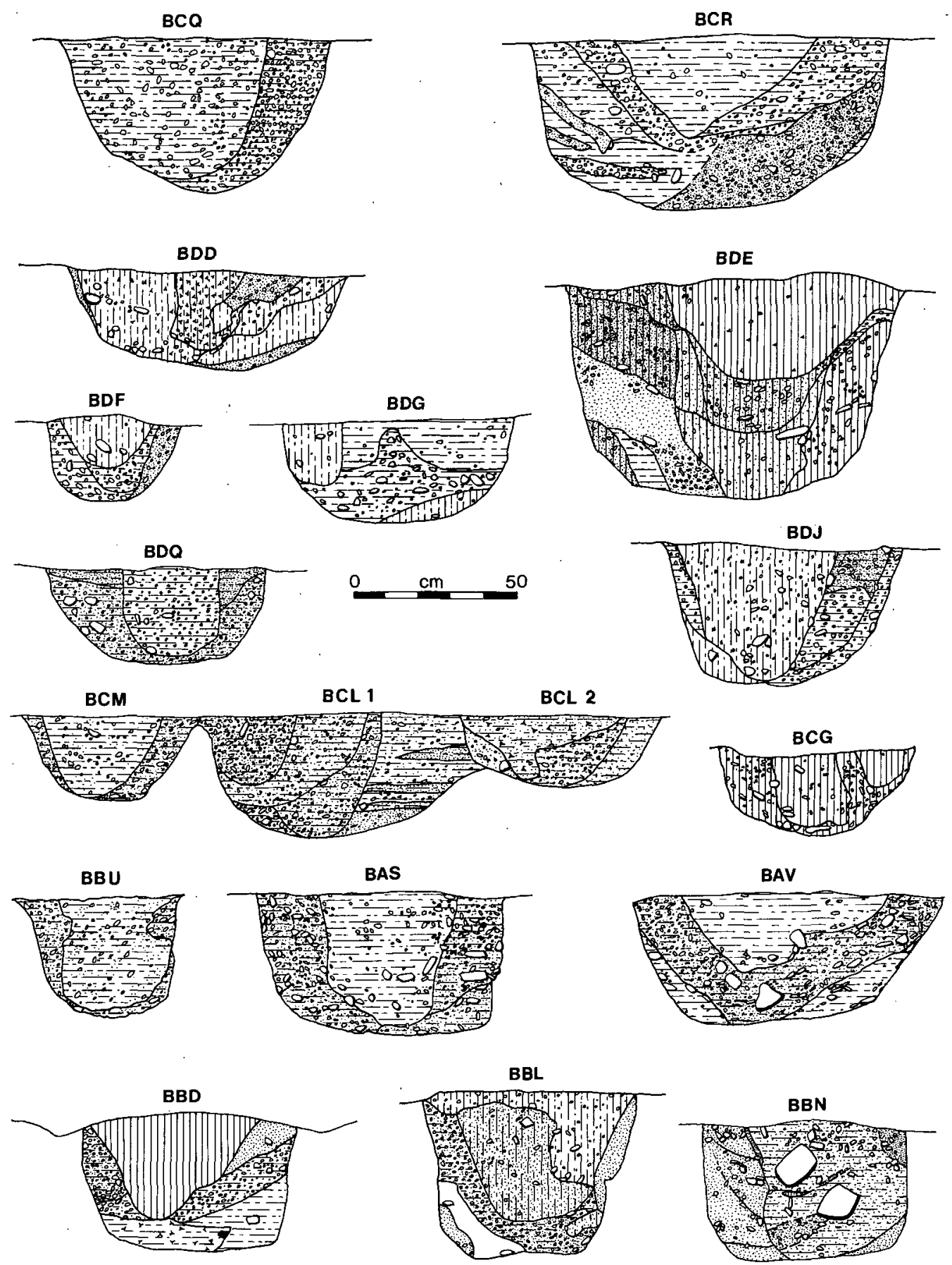

ILLus 4 Sections of the features of the Neolithic enclosure 
514

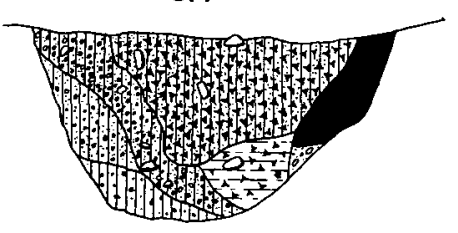

BAQ

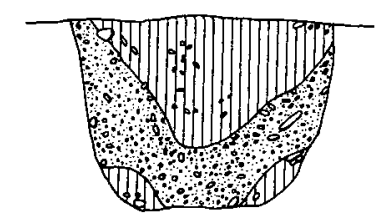

503

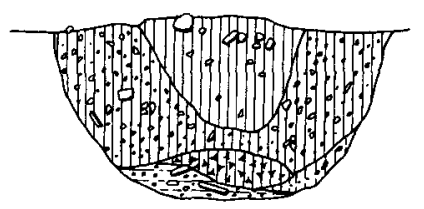

BAH

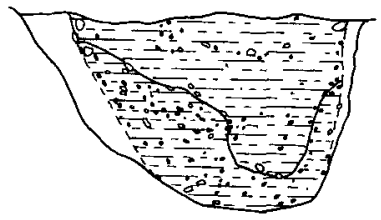

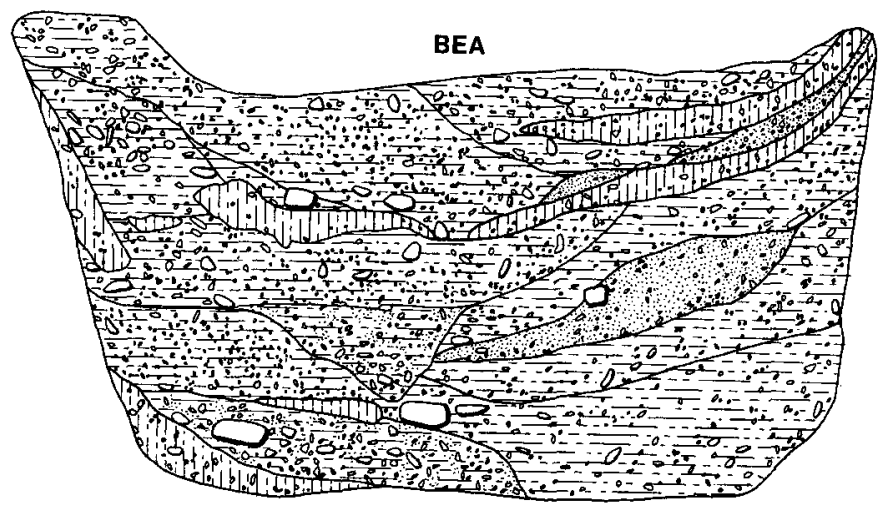

एIII] loam

$E \equiv$ silt

ilivin silt/loam

$\because \because \because$ gravel

sand

Fin charcoal flecks

charcoal

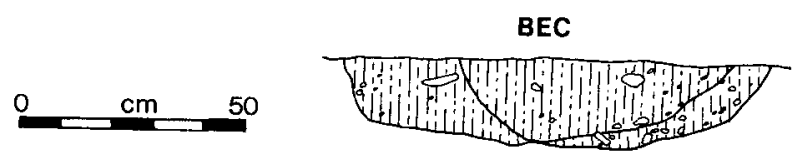

ILLus 5 Sections of the features of the Neolithic enclosure, and pits BEA and BEC

the centre of the pit towards the base (marked BEA on illus $2 \& 5$ ). The fill did not respond positively to onsite phosphate tests. Seemingly the pit had been dug, backfilled immediately and subsequently used to support a post. Emptied, the pit measured $2 \mathrm{~m}$ by $1.9 \mathrm{~m}$ and was $1.09 \mathrm{~m}$ deep. The sides were steep to vertical and the bottom flat. There was no stratigraphic relationship, and no dating evidence to connect this pit to the enclosure.

The pits to the west of the enclosure were shallow and did not contain any evidence of post settings or other use. Fragments of pottery were found in one of the pits.

\section{SITE F}

During a watching brief undertaken at the end of the project, close to the 'pig-trap' at the core of the British Gas development, to the east of the Neolithic enclosure, 23 pits and post-holes were investigated. Their location is shown on illus $1 \& 6$. The features could be grouped into four different categories: shallow depressions (5), post-hole type features (9), larger oval pits, usually straight-sided and flat bottomed (5) and those which contained pottery (4). It was possible only to date those containing pottery - Neolithic pottery was found in FAA, FAC and FAE, and Beaker sherds were found in FAG. FAE was a flat-bottomed, straight-sided shallow depression containing charcoal-stained soil. In the centre of the feature were burnt stones; a large quantity of pottery lay in the centre, on top of a stone. 


\section{THE POTTERY}

\section{Trevor G Cowie}

The pottery cannot now be located; fortunately, shortly after the excavation, some of the pottery was shown to this author for comment, and the following brief comment is based on notes and sketches made at the time. The only significant sherds were found during the watching brief in 1980 (site F). The decorated Neolithic pottery is described and illustrated in Cowie (1993) and that report is not repeated here.

The Beaker sherds are in two groups:

1 Ten sherds and fragments of Beaker (mostly decorated); light reddish brown exterior with a grey core/interior (illus 7). The fabric is friable; fine clay matrix with crushed micaceous and quartzite inclusions. Feldspar/quartz/biotite; decaying granite. Gritty.

2 One sherd possible Beaker lacking micaceous inclusions. Size $31 \times 23 \times 8 \mathrm{~mm}$. One large grit c $10 \mathrm{~mm}$. Hard fine clay matrix; light reddish brown exterior; grey core/interior. Decoration - line of fingernail impressions. Indeterminate.

\section{DISCUSSION}

\section{G J Barclay}

The enclosure was evidently an unroofed structure, a span of some $20 \mathrm{~m}$ being too great to roof without further internal post support, for which there was no surviving evidence. It is likely that it took the form of a stockade, perhaps with horizontal elements linking the upright posts. There were a number of possible entrances where posts were far enough apart in places to allow access between them, and where posts offset from the wall lines might indicate deliberately constructed gaps.

The enclosure was split into two parts by the transverse line of posts. The shape of the enclosure immediately suggests that it had been constructed in two parts. The aerial photograph (illus 3) showing the enclosure during excavation from the north illustrates very clearly that the northern part is more strictly rectangular than the southern - indeed the sides of the southern part are distinctly bowed. The junction between the two halves on the west side (the right side on the photograph - the point marked ' $a$ ') bears closer scrutiny. It appears that the south-west corner of the northern half (the near half on illus 3) stops at a point outside the place where the side of the southern half starts. At the other (east, or left-hand) side, the wall of the southern half also seems offset slightly to the east (point ' $b$ ' on illus 3 ). The impression is that the transverse division belongs to the northern half. It may be suggested that the northern part was perhaps built first.

However, it is possible that what, in its final form, appears to be a bipartite enclosure, did not from the first operate as one, and then as two enclosed spaces; alternative interim forms may be suggested. It is difficult to provide an explanation for the differences between the number and spacing of the posts on the east and west walls north of the division (30 as opposed to 20). It would be unwise to assume that the two walls served exactly similar functions - for example might the east wall have held up a barrier of some kind, while the west was permeable? There are a number of possibilities. One is suggested by differences in post-hole alignment and size marked by the pairs of arrows on illus 2, midway along all three of the transverse elements. At the marked point the southern wall seems to be divided into two parts, each bowed to the south. Might the structure have stood as an open ' $E$ ', facing either east or west at one stage in its use, before being completed by the addition of a second, similar element? Alternatively could these discontinuities mark 


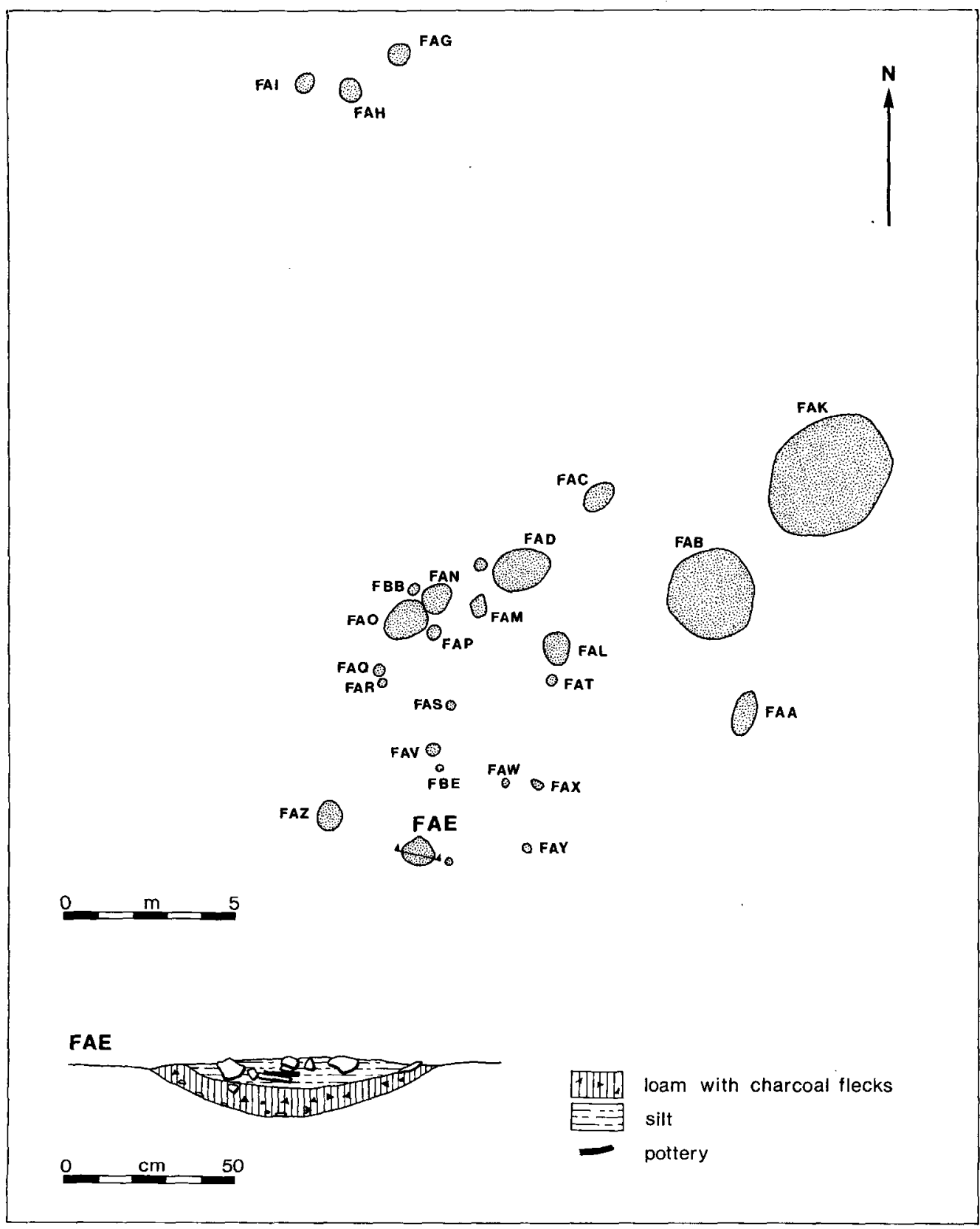

ILLUS 6 Plan of area F and sections of FAE and FAG 

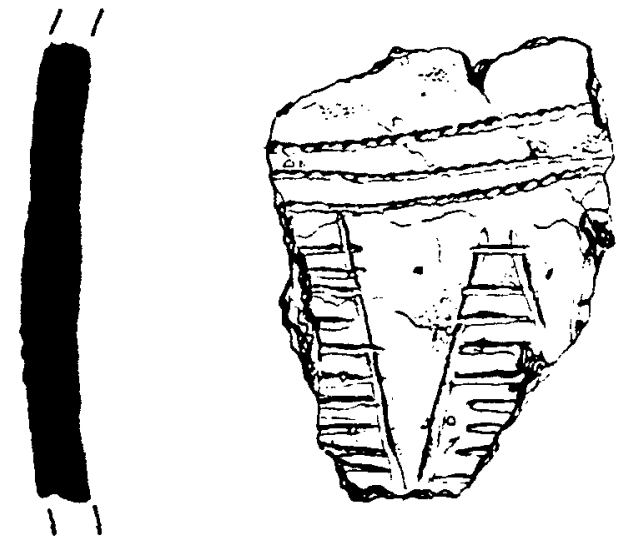

ILLus 7 One of the sherds of Beaker pottery found in area $F(1: 1)$

slightly offset entrances built in the barriers? The aerial view of the site during excavation (illus 3 ) shows the discontinuity in the northern wall very clearly. The differences between the eastern and western walls is emphasized by another feature of their construction; the eastern wall (right hand on illus 3 ) of the southern (further) half of the enclosure appears to be made of almost straight segments. In general, the whole eastern wall is less even in line than the western. Other entrances may be suggested, for example at 'c' on illus 3 and there are other discontinuities in the lines of the walls.

A substantial, unroofed enclosure of the Neolithic can only be open to a small number of interpretations. Since the excavation was undertaken the number of broadly comparable sites has grown and there is more excavation evidence. While the parallels presently available in the UK for Douglasmuir suggest to this writer that it had a ceremonial function, such is the dearth of evidence for domestic structures of the period that a fully domestic use for the enclosure (perhaps in the Neolithic agricultural economy) remains a distinct possibility.

\section{PIT-DEFINED STRUCTURES IN SCOTLAND}

There is a growing number of rectangular or parallel-sided pit-defined sites appearing as cropmarks in Scotland. Tayside provides the greatest range and quantity of data and their present known distribution has been mapped by RCAHMS (1994) and Barclay (forthcoming). The Douglasmuir enclosure bears a resemblance to part of the nearby Balneaves cursus monument (illus $1 \& 8$ ), a typical Scottish pit-defined cursus variant. Its visible length is $450 \mathrm{~m}$ but only the north-east terminal has been photographed. At the north-east terminal the last $100 \mathrm{~m}$ is separated from the rest by a transverse line of pits very similar to that at Douglasmuir. Indeed, this terminal 'enclosure' seems from the visible evidence to be an addition to the cursus, or it might be that the cursus is added to it. This arrangement has also been observed at the cursus monuments at Kinalty (illus 8).

To the west, at Bennybeg (NN 865190), there is a rectangular enclosure measuring about 110 $\mathrm{m}$ by $35 \mathrm{~m}$ with bowed sides. From the north-east and north-west corners of the enclosure two lines of larger pits run for about $30 \mathrm{~m}$. In the same field are the remains of a pit circle (Tolan 1988).

Our understanding of the Scottish material suggests that in some cases pit-defined and ditch-defined enclosures may be interchangeable - for example, we appear to have both types of cursus in Scotland. It is therefore prudent to consider here comparable ditch-defined enclosures. Loveday \& Petchey (1983) have discussed the phenomenon of the rectangular enclosure in the Neolithic and concluded that there is a strong case for cursus monuments and long mortuary enclosures being part of a continuum, from the largest to the smallest. The segmented nature of cursus monuments, notably in the cursus/bank barrow known as the Cleaven Dyke (Barclay et al 1995), suggests that their construction may have been undertaken over a considerable period, in segments. 


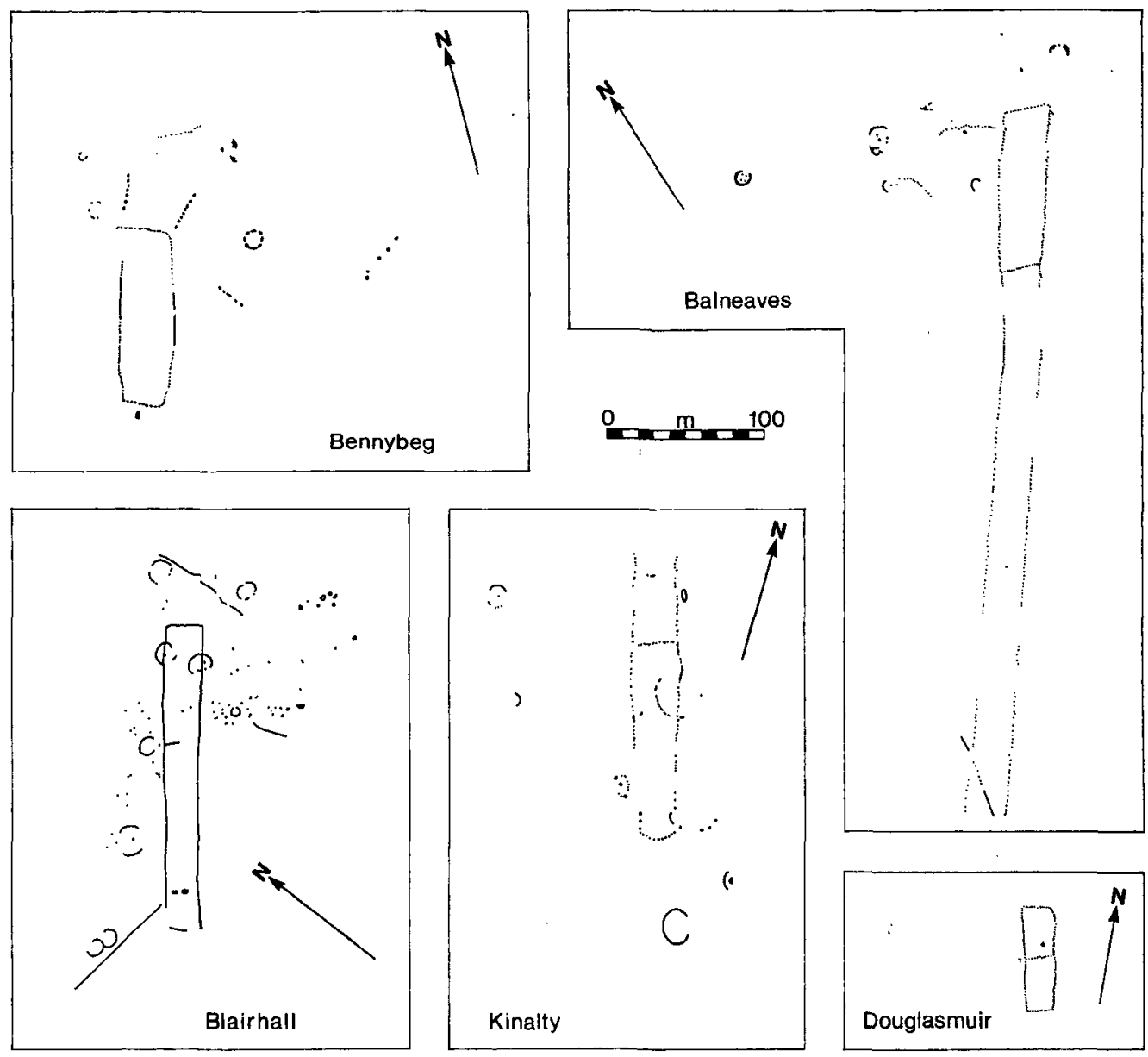

ILlus 8 Pit-defined sites in Scotland. The plans of Kinalty and Bennybeg are based on computer transcriptions by RCAHMS of oblique aerial photographs

The ditch which defined the enclosure at Inchtuthil (Barclay \& Maxwell 1991) had been used to support a fence which had subsequently been burned in situ. While the Douglasmuir and Inchtuthil enclosures are not similar in detail, they are broadly contemporary and both fit into a picture of early Neolithic ceremonial structures familiar from the north-east of Scotland to southwestern England (cf. Dorchester (Whittle et al 1992)). The only possibly domestic structure of this period presently known in eastern Scotland - the building at Balbridie (Ralston \& Fairweather 1993) - is not in any way similar. The rather later funerary and ceremonial structure at Balfarg (Barclay \& Russell-White 1993) is smaller and more complex. It should be noted that a substantial part of a Neolithic stone axe was found during the excavation of the Iron Age settlement at Douglasmuir, and is reported upon below. 


\section{THE IRON AGE SETTLEMENT}

\section{Jill Kendrick}

On the same group of aerial photographs on which the Neolithic enclosure appeared, four horseshoe-shaped features of apparently variable size were noted (illus 9). It is possible that prior to the first modern ploughing of the field, some signs of these features were visible as shallow earthworks; this was also suggested during excavation by the presence of recent ploughsoil in some of the features. A photograph taken in 1979 by Michael Brooks, of the Central Excavation Unit (Scotland), revealed one more circular cropmark, bringing the total to five before excavation.

The excavation was restricted by time and resources to the areas around the most obvious cropmarks. However it was evident from the aerial photographs and subsequent excavation that the

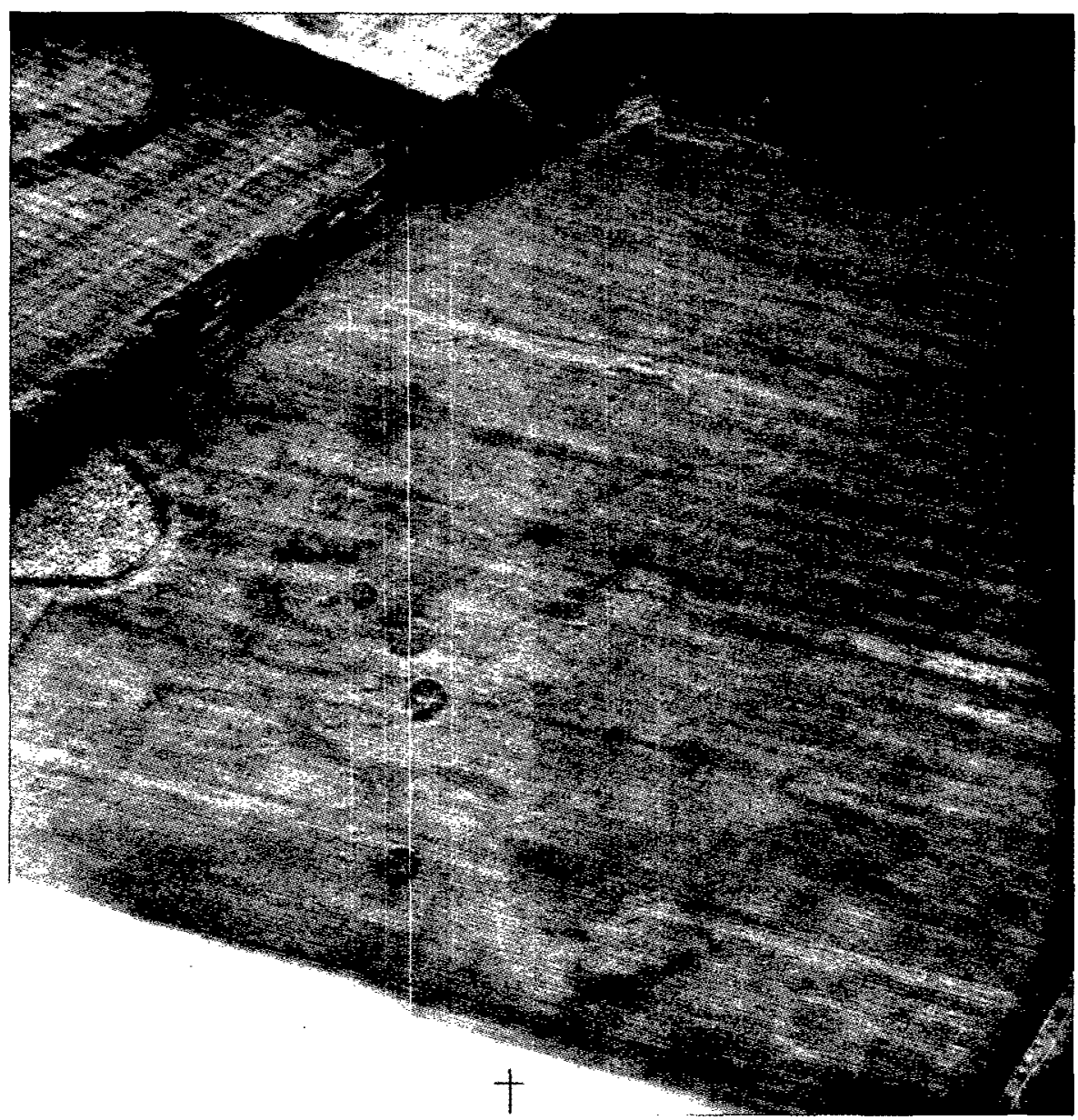

Illus 9 Aerial photograph of the Iron Age settlement site taken by J K St Joseph (Copyright: Cambridge University Committee for Aerial Photography) 
field was densely covered with archaeological remains. The penannular ring-ditches will be referred to as houses throughout this report.

The major features of the site were clearly visible on the ground in the growing cereal crop in July 1979, and it was possible to lay out a trench before the crop was cut. The effect of the buried features on the growth of the crop above was striking, for not only was there extra growth but the cereal retained its green colour longer than the surrounding crop. Professor St Joseph's photograph had been taken in low light, when the marks were emphasised by the shadow cast by the taller stalks (illus 9).

\section{THE EXCAVATION}

\section{Methods of excavation and sampling}

In 1979 two of the houses, 1 and 4, were excavated. In 1980 a trench was laid out with the aim of including the houses and the areas surrounding them, and large parts of the site that at first appeared featureless, for example between Houses 4 and 5 and to the south and west of House 2. A trench was also placed over a large amorphous feature that was subsequently revealed as House 6 . A total of about $3,500 \mathrm{sq} \mathrm{m}$ was stripped of topsoil to within about $0.05 \mathrm{~m}$ of the subsoil surface with a JCB back-actor using a 5 foot wide toothless bucket. Limited examination of the topsoil was possible during machine stripping and it yielded only modern finds. The site was subsequently hoed to the surface of the subsoil, where the features first became apparent, and then trowelcleaned repeatedly, in various conditions during the excavation. Unfortunately, calm, damp periods, the ideal conditions to observe features, were rare, and it is possible that some small features were missed.

Features were excavated in a variety of ways, the most efficient and informative being a half section incorporating a series of reduced half plans, providing several plans at different levels as well as a section drawing. The penannular ditches were marked out with a number of sections, both radial and axial, through what seemed to be potentially informative areas, but these were often repositioned as excavation progressed. Only in House 6 were quadrant-type sections established and adhered to.

Samples were taken from all significant features and were successfully floated for organic material. The carbonised seeds recovered by flotation were identified by David Habershaw. They, together with the quernstone fragments, show that wheat, barley and oats were cultivated by this community. Brief summaries are presented with the description of each structure - further detail is available in the archive. Samples were also taken for radiocarbon dating.

\section{Subsoil}

The subsoil consisted of gravel and sand in bands across the site, and an area of silt near House 1 (illus 10). The gravel varied from small, compacted stones through medium gravel to coarse, loose gravel. Sand-cut features had been more heavily damaged by ploughing than those cut into gravel; many of the smaller features had to be dealt with in one day as they disappeared in the frequent sandstorms if left overnight. This applied in particular to the six-post structure B. Likewise the sandy base of the ditch in House 6 eroded rapidly after it had been revealed. Animal, worm and root activity was considerable. Soils in the features were thus mixed and habitation layers were not discernible. It is probable that ploughing had removed the upper levels of the house floors.

\section{Pre-construction activity}

Activity on the site was apparently widespread, and was present not only in the area of the settlement but also in other parts of the field. However this discussion will be confined to those features that definitely predated the settlement in that they were found in clear stratigraphic association with it. Only in such cases could phases of occupation be detected; normally the separate elements of the site were not stratigraphically related and may also have been separated in time. 


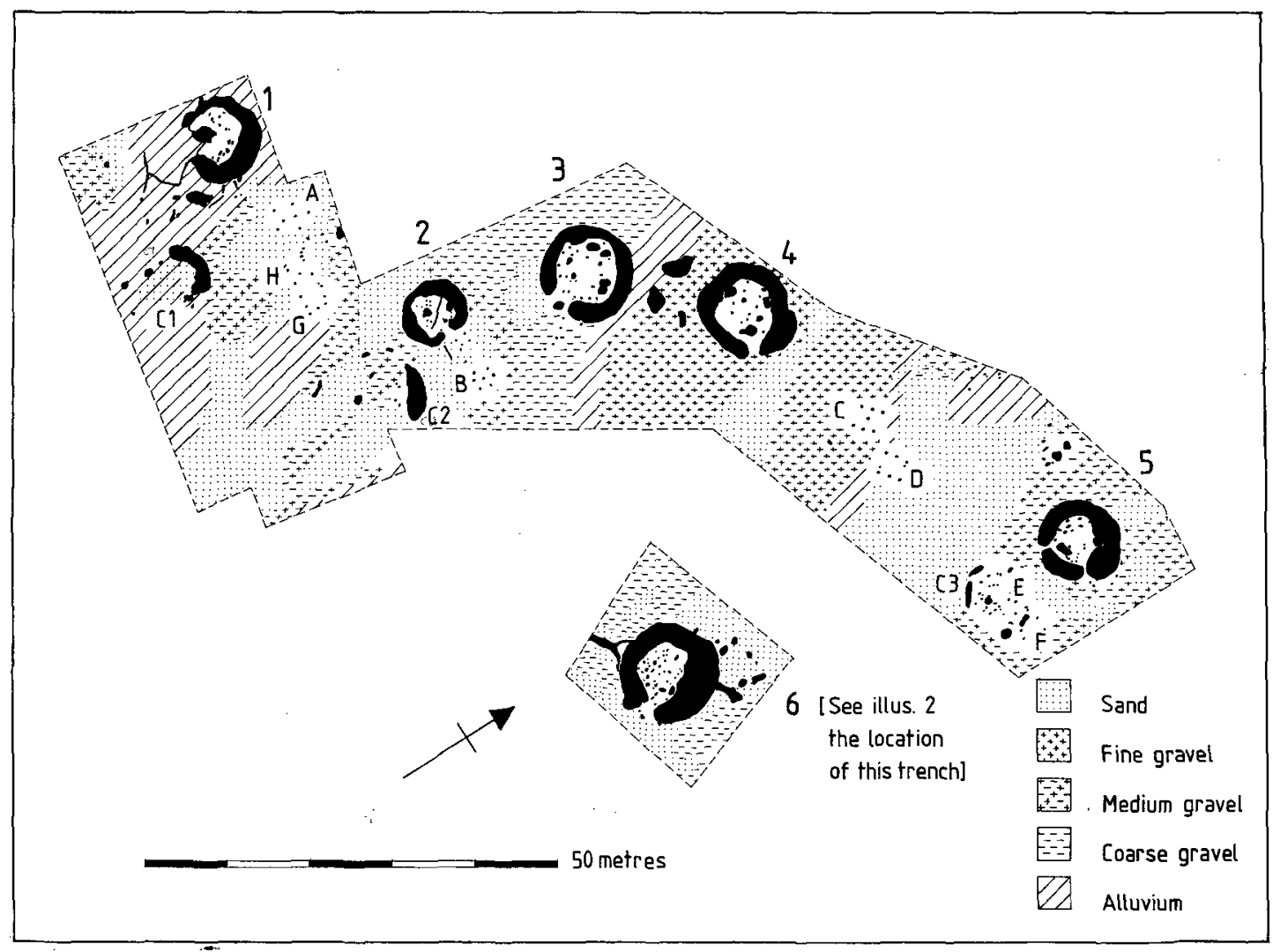

ILLus 10 Plan of features of the Iron Age settlement before excavation, showing underlying subsoil variations

A series of small gullies traversed the excavation area at its western end, crossing the areas where Houses 1 and 2 were later built, and truncated in places by the house foundations. In form they were narrow, intermittent, and not more than $0.15 \mathrm{~m}$ in depth, having small post- or stake-holes placed along their length at intervals of $0.1-0.2 \mathrm{~m}$. In both Houses 1 and 2 some of the holes within the gully had been re-used as postholes in the interior of the house, therefore it is probable that the houses post-date the gullies by only a short time and represent an earlier phase of the settlement. The gullies have been interpreted as fence slots.

\section{THE SETTLEMENT}

\section{THE DOUGLASMUIR HOUSE-TYPE}

Topsoil stripping revealed, in each house, an irregular penannular area of dark soil cut into the gravel or sand subsoil. When excavated each proved to be a penannular ditch of a distinctive type (illus 11). Irregularities in the edge of each feature were most frequently caused by pits in the interior, having one of their sides on the slope of the ditch and sharing an upper fill with the ditch. The ditch fills were commonly of a dark silty loam, quite stonefree, becoming more gravelly and sandy towards the base, but often with isolated patches of charcoal. In many cases a greyish clayey deposit, later identified as the remnant of a gleyed horizon, covered the base of the ditch to a depth of $20-30 \mathrm{~mm}$. Likewise paving covered the base of the ditch to a varying extent in each structure.

An important characteristic of the Douglasmuir houses was their distinctive profile. One description can 

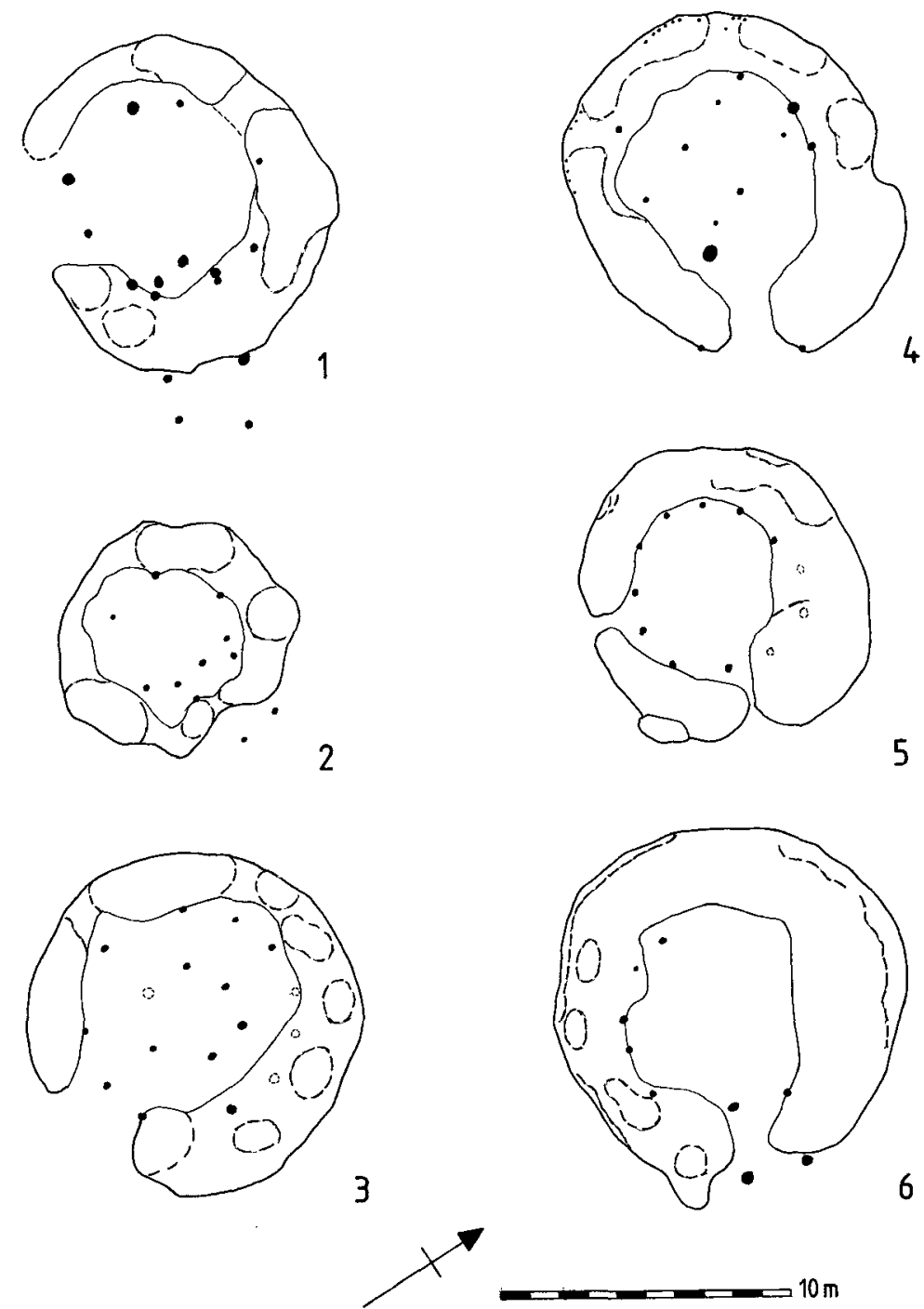

ILlus 11 Comparative plans of the Douglasmuir houses showing probable structural postholes

be broadly applied to all. The outer face of the ditch was steep or vertical, the bottom flattened and covered in places with paving stones. The inner edge sloped gradually upwards towards a central area that, in all but House 6 , was on a level with the present natural subsoil. The breadth of the ditch varied from $1 \mathrm{~m}$ to $2.2 \mathrm{~m}$ in Houses 1 to 5 and in House 6 was as much as $3 \mathrm{~m}$. The ditches of Houses $1-5$ varied in depth from $0.1 \mathrm{~m}$, where plough action had been particularly destructive, to $0.45 \mathrm{~m}$. House 6 was exceptional in the great depth of its ditch.

None of the houses had a ditch of even depth, but rather there was a markedly scooped appearance to the ditch so that it resembled a series of shallow pits or bays. The area enclosed by each ditch contained a 
number of post-holes, from 17 in House 2 to 43 in House 6, as well as a number of pits. Not all of these are considered structural, the probable location of the structural posts being shown on illus 14. The post-holes of House 5 only are illustrated here, drawings of the others being stored in archive. Due to the degradation of the original soils it has not been possible to interpret the various pits found and they are not described in detail here. Further information is available in the archive.

\section{HOUSE 1 (ILLUS $12,13 \& 14$ )}

House 1 had been built on the crest of a slight ridge and was the most westerly feature excavated. It was quite badly truncated by ploughing since the subsoil was a friable mixture of sandy gravel, sand, and a deposit of silt. It was apparent on the ground as a raised area in the cereal crop but did not show as a mark from the air. This was perhaps the result of many large paving stones within the penannular ditch or, more likely, was because of an area of silt that surrounded it which reduced the contrast between the moisture-retaining capacity of the subsoil and the ditch fill.

It measured $c 11.5 \mathrm{~m}$ in diameter across a ditch $2.5 \mathrm{~m}$ wide, with a post-ring $6.5 \mathrm{~m}$ in diameter. It was the only house at Douglasmuir that had paving covering a substantial part of the base of the ditch and this rested, for the most part, directly on the subsoil. The break in the ring-ditch faced due south, and was flanked by post-holes on the inside but not on the outside of the ditch. The ditch terminal to the west was badly eroded and rather nebulous, as that part had suffered severe plough damage, surviving to a maximum depth of $0.15 \mathrm{~m}$. In this part of the ditch an earlier gully could be traced as a slight groove beneath the fill of the ditch and was sealed by some of the paving. The gully was also cut by a pit $1 / 1$, in which no trace of it survived. It continued to the east of the pit where it was abutted along its eastern edge by the ditch terminal. Post-hole $1 / 2$ seemed to be an enlargement of a gully stake-hole to form a structural post-hole. Of the 11 main post-holes within House 1, six showed post-pipes in section. They varied in depth from $0.15 \mathrm{~m}$ to $0.42 \mathrm{~m}$, although the average was $0.32 \mathrm{~m}$. The diameter range was from $0.14 \mathrm{~m}$ to $0.48 \mathrm{~m}$, although again the average fell towards the larger end of the range at $0.33 \mathrm{~m}$. Of the remaining post-holes, the average depth was $0.26 \mathrm{~m}$ and the average diameter was $0.40 \mathrm{~m}$. In all cases the fill was a dark brown sandy loam with a small stone and gravel content. These post-pipe sizes were comparable with those found in the other houses.

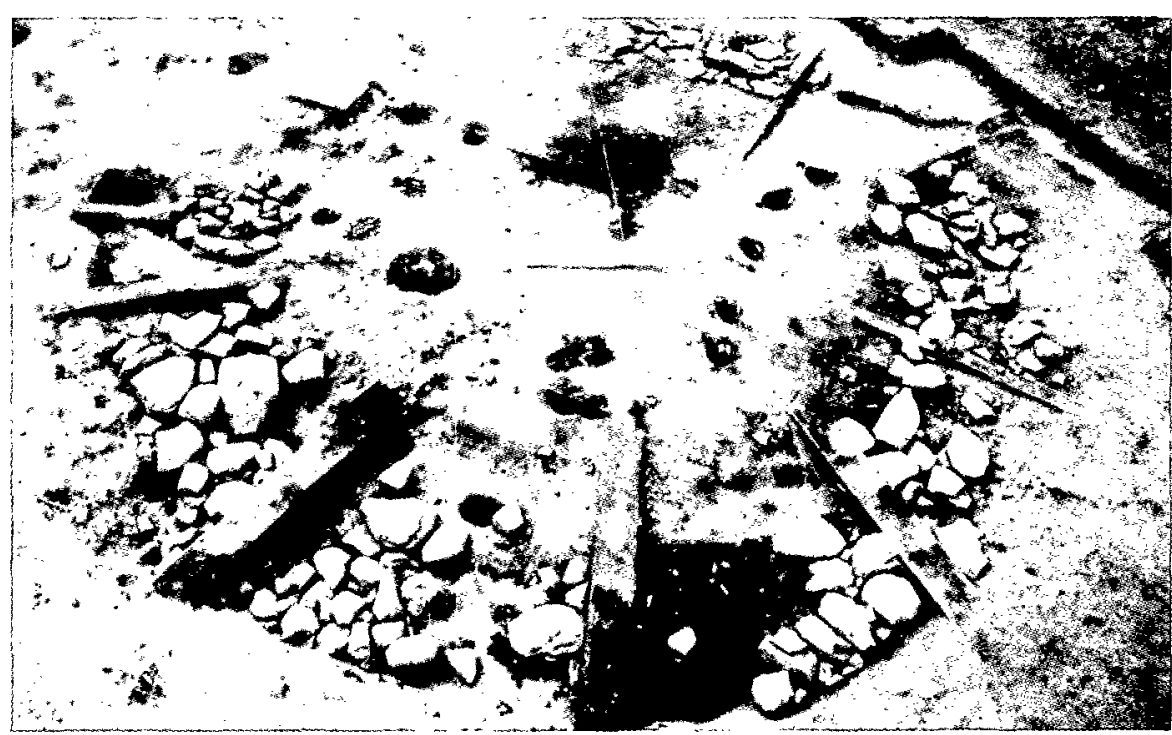

ILlus 12 House 1: paving in base of ditch 


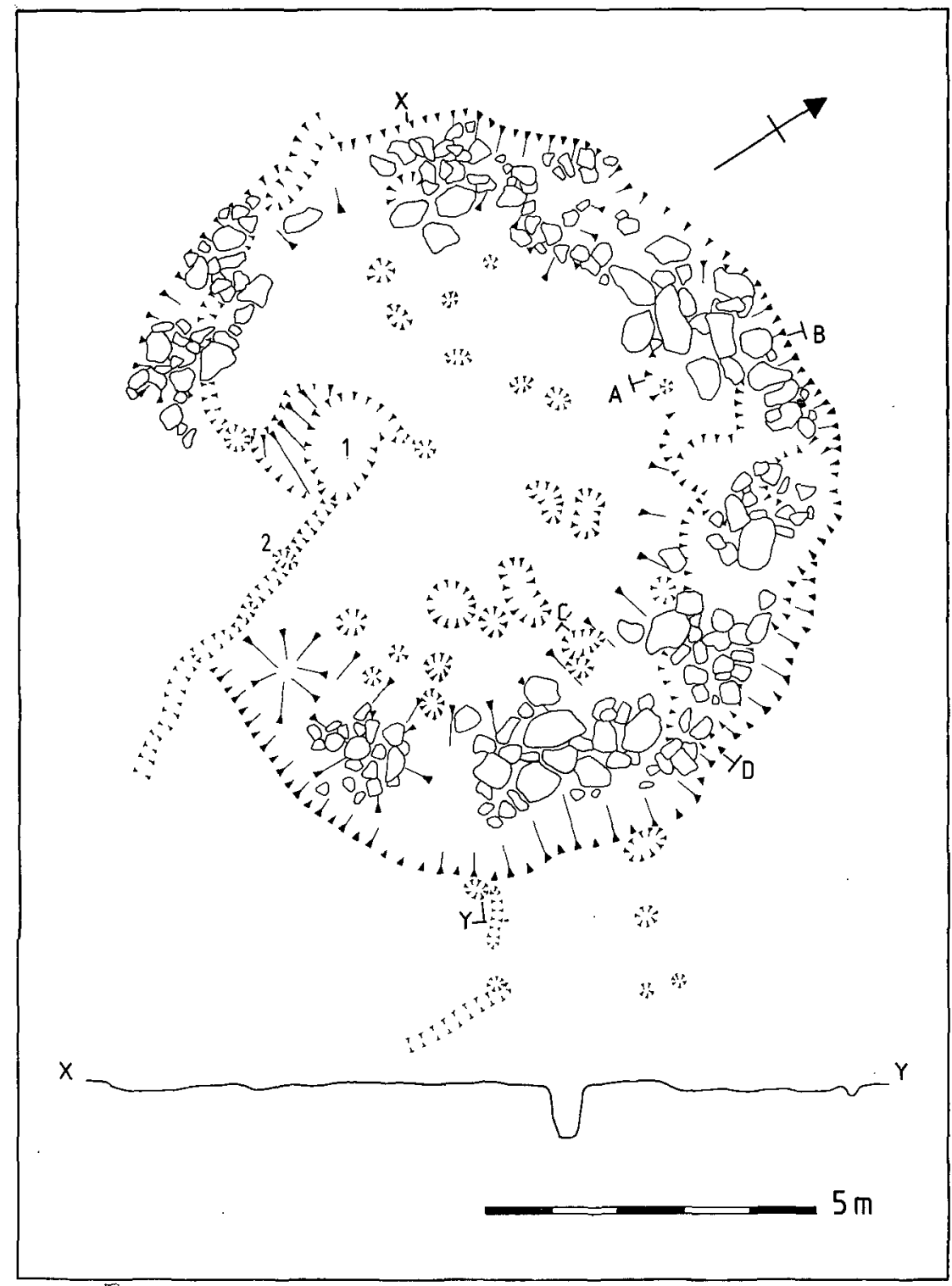

ILlus 13 House 1: excavated plan and profile

In the south-east the ditch had been backfilled with large stone slabs, which brought the level up to slightly above present subsoil surface. This was higher than the rest of the paving, and formed a causeway across the ditch. Thus the causeway was apparent after the topsoil had been stripped and before excavation had started. Four post-holes flanked the causeway on either side and two more occurred at about $1.2 \mathrm{~m}$ from the ditch edge. This may mark a remodelling of the house from a structure with an entrance in the south-west to one with an entrance in the south-east. Three post-holes, interior to the ditch, formed a line behind the causeway, and this feature can be seen on other houses $(2 \& 6)$. The arc of posts at the north end of the house and associated with a shallower part of the ditch may also mark some form of interior division. 


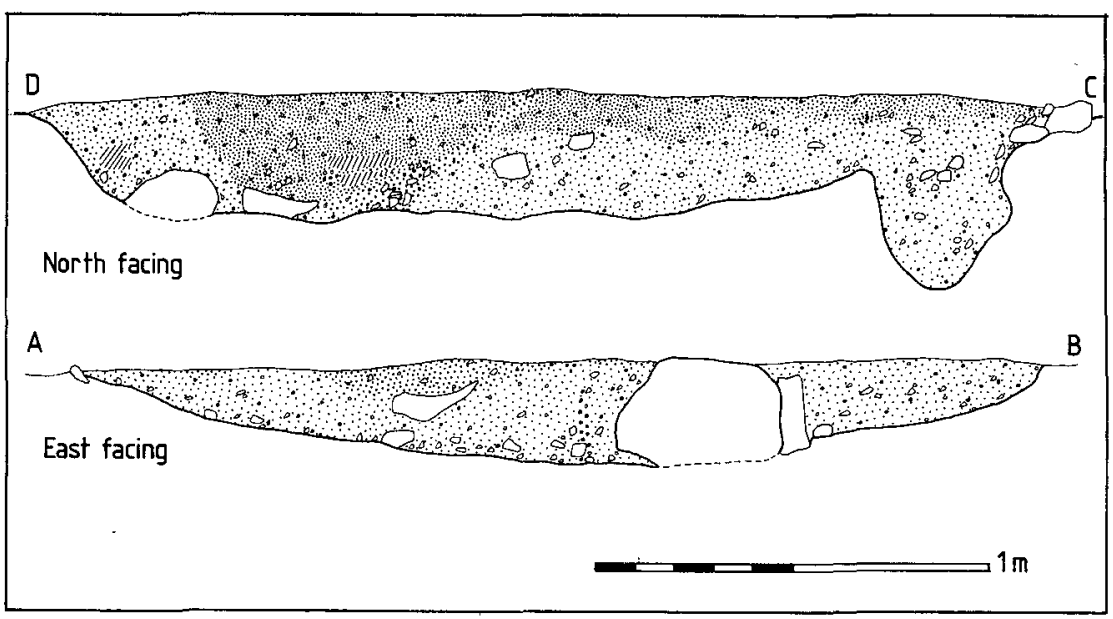

Illus 14 Sections through the ditch in House 1

The ditch fill was generally a dark, silty, fairly stone-free loam, extensively disturbed by animal and worm action. The upper layer tended to be darker and less stony than the lower and had a high modern ploughsoil content. The lower layer was more gravelly although still very dark in colour. A pit in the centre of the house cut through the line of the gully. It contained several roughly flaked flints, and a large amount of charcoal, which was submitted for a radiocarbon determination (GU-1466: 766-408 cal BC). The fill at the edges of the pit merged imperceptibly with the alluvium into which it was cut, so it was difficult to assess the original shape and size. It was the only large pit within the interior of the house.

Finds within the house included fragments of 10 quernstones, one polishing stone and one spindle whorl fragment; three chert and three flint flakes were also found.

\section{HOUSE 2 (ILLUS $15 \& 16$ )}

Excavation showed that this house was $8-8.5 \mathrm{~m}$ in diameter from the outer edge of the ditch, the maximum width of the ditch being $0.8 \mathrm{~m}$. The post-ring was c $4.5 \mathrm{~m}$ in diameter with only five post-holes of this ring surviving. To the east part of the ditch, a marked shallowing was flanked by four post-holes. A narrow groove connected the most easterly post-holes; as there was some animal disturbance in this area, this groove may not have been an archaeological feature. Three post-holes were aligned inside the house at right angles to the shallow part of the ditch or within this 'entrance'. This is a feature that recurs on several houses, and has already been noted in House 1. There was no sign of an inner ring of posts, though there may have been a small interior division on the west side of the house.

The form of the ditch was not that of a continuous circuit of even depth. Apart from the reduction at the entrance, the ditch was made up of four pits with intervening ridges. Three were elongated but one was a fairly regular bowl-shaped depression. The gully which ran through the house has already been mentioned; it was much slighter than those of House 1, although again an internal post-hole appeared on the line of the gully and may have been enlarged from an existing stake-hole. The fill of the penannular ditch was consistently a dark brown sandy loam containing charcoal flecks, with a frequently noted basal layer of grey or greyish-brown deposit. A layer of gravel mixed with soil occupied a position at the outer side of the base of the ditch fill. A typical section through the ditch of House 2 is shown in illus 19.

Finds from this house included four quern fragments, one stone with a deeply worked hollow in one face, two polishing stones and one chert flake. 


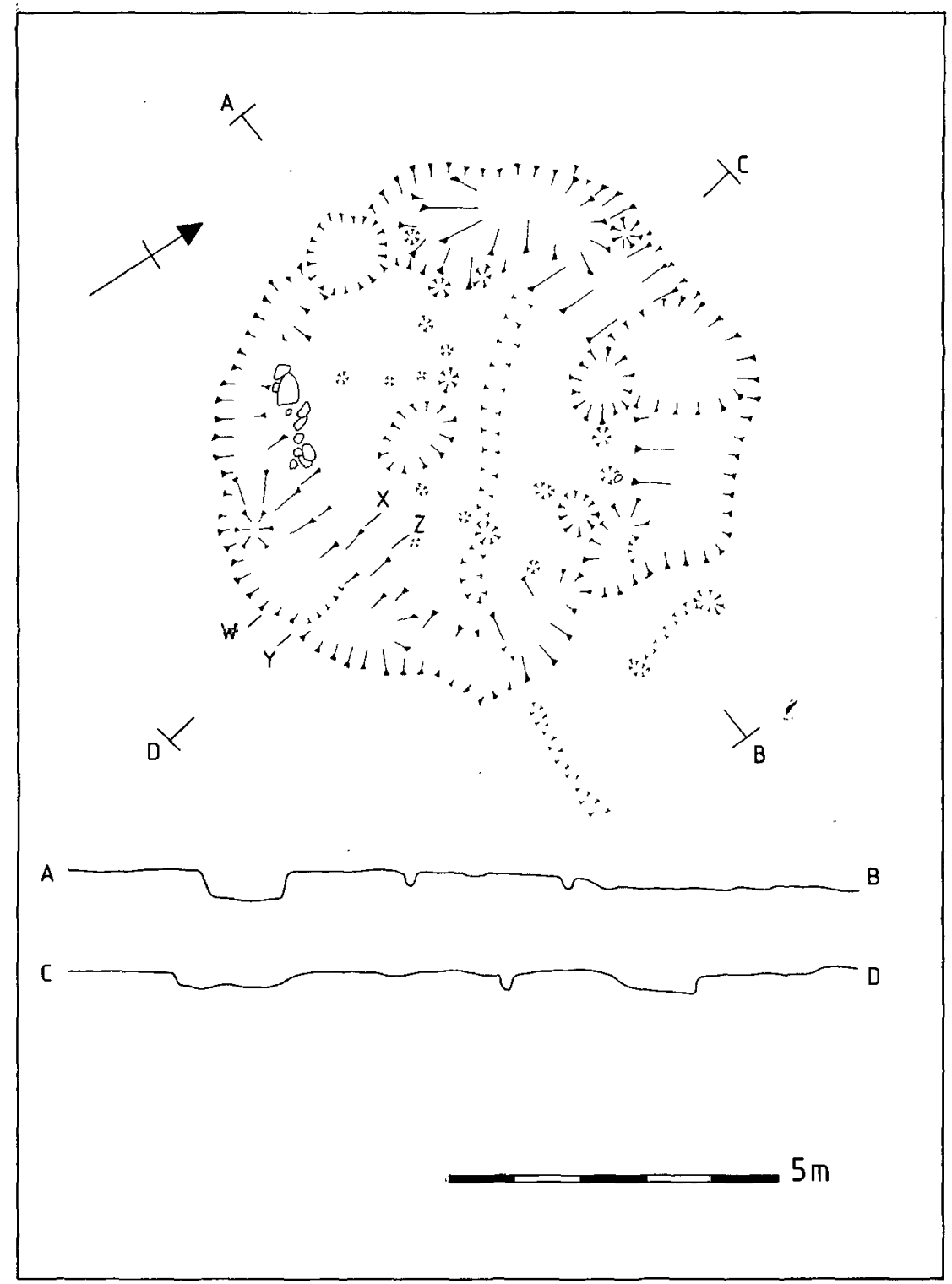

ILıus 15 House 2: excavated plan and profiles

HOUSE 3 (ILLUS 17)

House 3, measuring approximately $11.5 \mathrm{~m}$ in diameter, was the second largest on the site, but one of the least well preserved. The west side of the penannular ditch had been dug into sand and therefore was much more susceptible to plough damage; it had survived only to a depth of $0.1 \mathrm{~m}$ at some points. The gravel subsoil into which the east part of the ditch had been dug was coarse and loose; nevertheless the outer ditch edge was, in this area, sometimes overhanging. The ditch was segmented into a series of shallow pits, which included on 


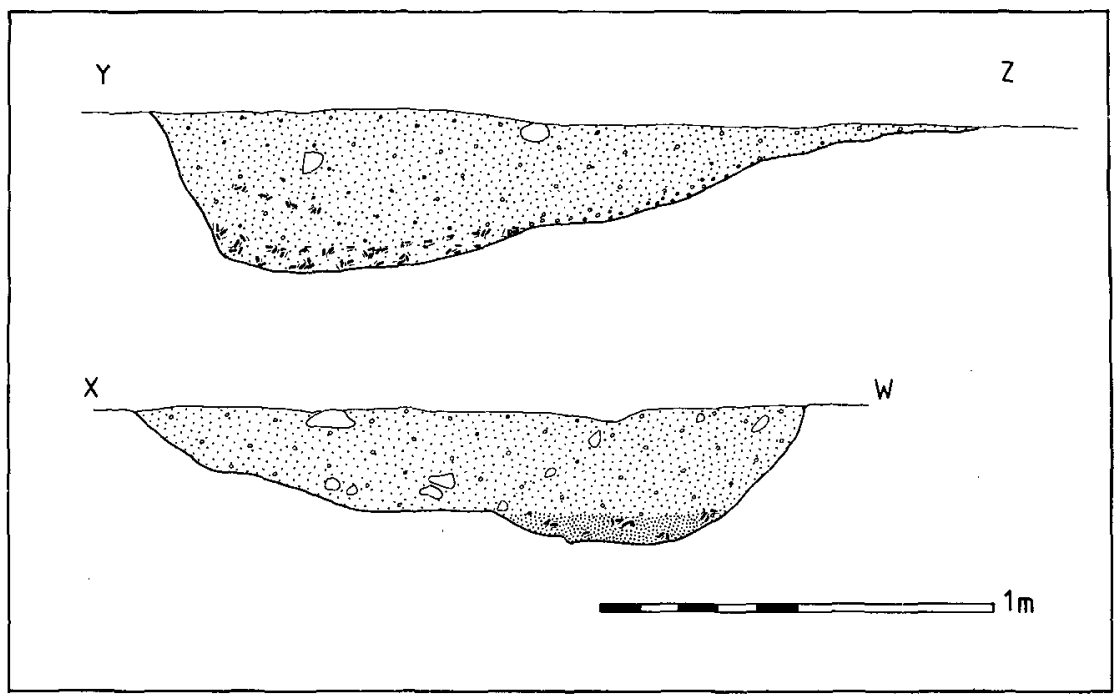

ILLUS 16 House 2: ditch section

the east side an almost rectangular stone cist-like feature. In others some residual paving remained. The large pebbles of the gravel subsoil provided a solid base to the scoops on this side.

An almost complete circle of 10 post-holes $\mathrm{c} 7 \mathrm{~m}$ in diameter had been dug into the inner lip of the ditch, with a concentric inner circle about $4 \mathrm{~m}$ in diameter. Uniquely to this house, some of the post-holes had been packed with stones, emphasising the friable nature of the subsoil in this part of the site. A line of five posts extending from the east side of the entrance may have formed a wind break or have formed part of a fence line that did not elsewhere survive. Six large pits occurred in the interior of the house; one was placed in the gap between the ditch terminals. Some of the pits contained large stones, and were deep and straight sided. Paving occurred sporadically in the ditch, particularly in the north part where it clustered into two groups. The fill of the ditch was similar to that in all the Douglasmuir houses, being a dark sandy loam, fairly stone-free and flecked with charcoal with a basal layer of dark grey, slightly clayey soil.

Finds included two quernstones and a stone with a deeply hollowed upper surface (in two fragments from separate locations within the ring-ditch). Eleven grains of barley, four of wheat and two of oats were found in a sample taken from the base of the ditch and a further three grains of barley, together with two seeds of dock and one of chickweed, were found in a post-hole sealed by ditch fill.

\section{HOUSE 4 (ILLUS 18)}

House 4 was the first to be excavated, in 1979, and several elements that were puzzling at the time were elucidated by excavation of the rest of the site. The ditch was approximately $11 \mathrm{~m}$ in diameter, although the east side was considerably expanded by a later pit that was probably a tree-hole, indicated by the presence of a number of pine cones throughout its fill. (Part of a polished stone axe found in the upper layer of this pit must be regarded as a stray find.) Post-holes were dug into the inner lip of the ditch. Although they did not form a complete circle, it is thought that they represent the remains of a post-ring $6.5 \mathrm{~m}$ in diameter. In places around the outer edge of the ditch evenly spaced vertical depressions were apparent, effectively sectioned by the removal of the fill of the ditch, and not obvious before this had taken place. They were spaced about $0.2 \mathrm{~m}$ apart and are shown on plan. They have been interpreted as the remains of wattle stakes inserted on the edge of the ditch and are discussed later in the report. 


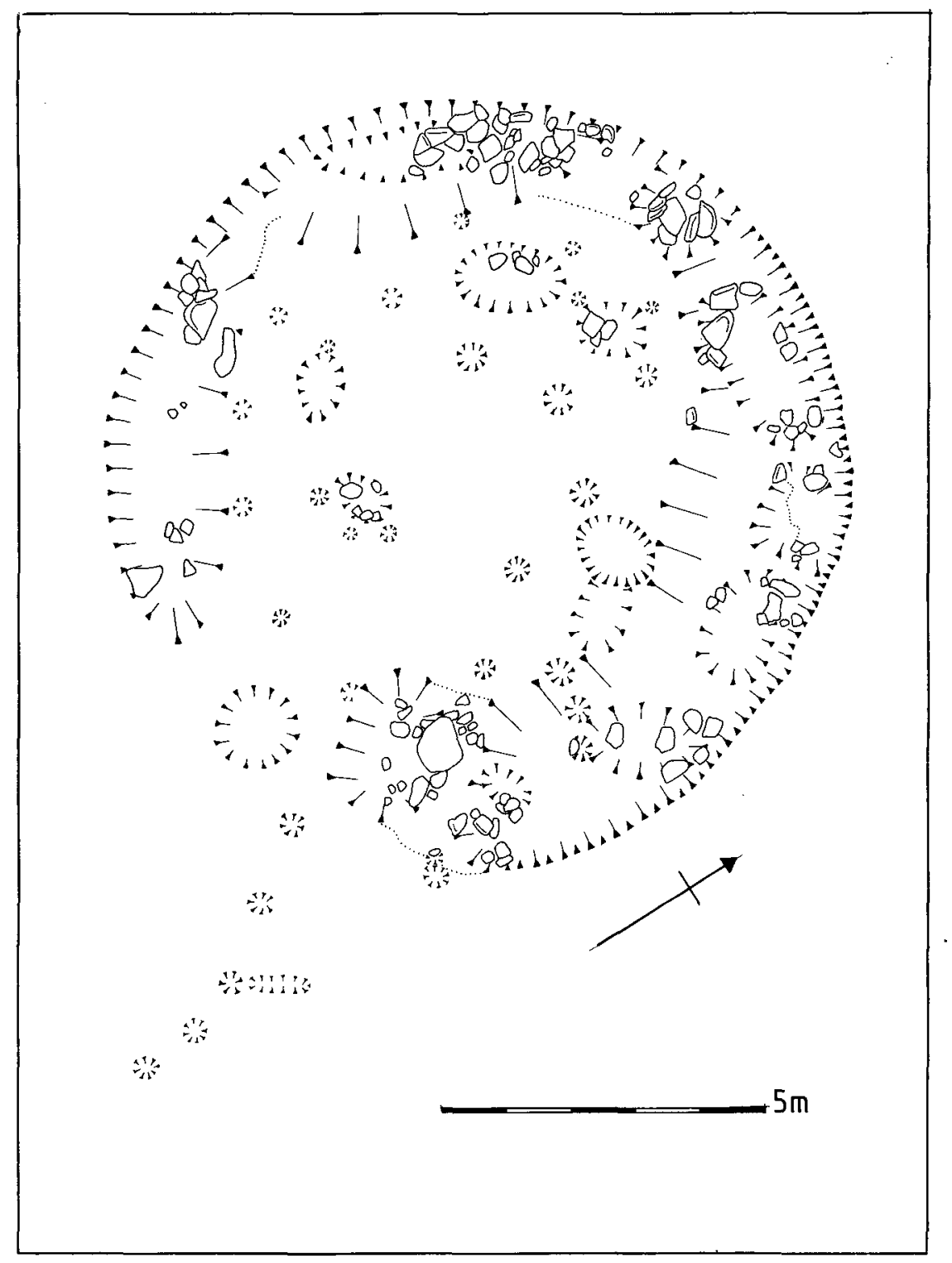

ILLUS 17 House 3: excavated plan

The ditch was dug into a band of fine, compact gravel, which varied in depth from $0.35 \mathrm{~m}$ to $0.75 \mathrm{~m}$, and commonly had a fill of dark brown silty loam containing sandy mottling in the lower part, with a basal layer of leached dark grey clayey soil. It was composed of four elongated scoops separated by 'causeways' about $0.2 \mathrm{~m}$ below the present surface of the natural subsoil. Sparse paving occurred in the base of the ditch and included a number of inverted quernstones. Near the west terminal of the ditch a deposit of fire-cracked pebbles was associated with a charcoal-rich deposit. One pit, $4 / 1$, in the house was of particular interest $(1.2 \mathrm{~m}$ by $1.0 \mathrm{~m}$, by $0.35 \mathrm{~m}$ deep). This pit had a fill similar to that of the ring-ditch, although with a higher 


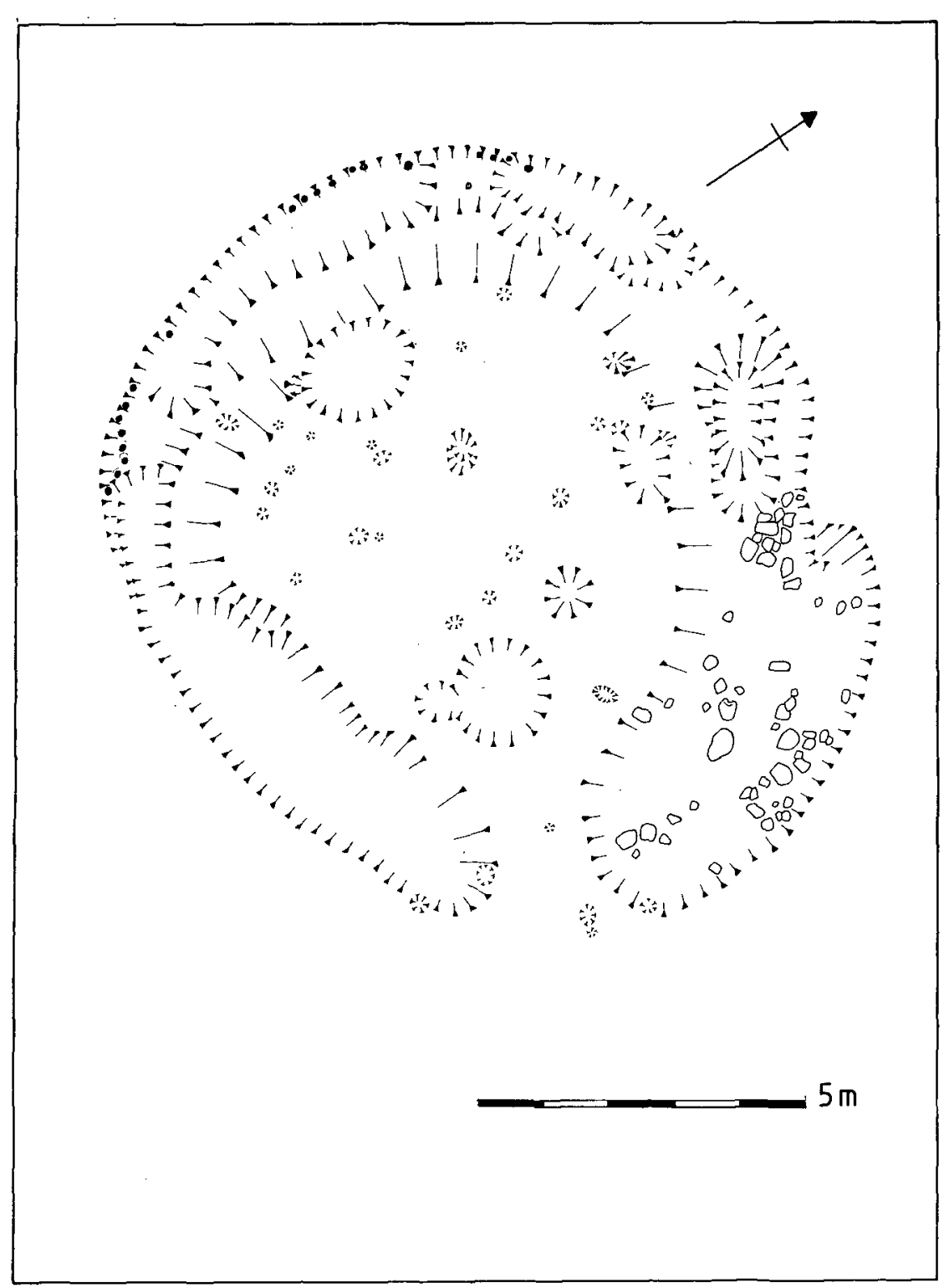

ILLUS 18 House 4: excavated plan

charcoal content, and a thick basal layer of dark, charcoal-stained loam. It contained a number of worked stone objects including a polished stone blade, a polished double-ended hammerstone, a concave saddlequern, and a large boulder with a smoothed surface, which was not removed from the site.

In addition to the items described above nine quernstones, one cupped stone with peck marks inside, seven polishing stones and three polishing pebbles were found. A soil sample from a large pit inside the ringditch (4/2) produced two seeds of wheat, two of spurry, one of couch grass and six of chickweed. A sample from a post-hole sealed by the fire-cracked pebbles on the west side contained six grains of barley and one seed each of spurry and hemp nettle. 
HOUSE 5 (ILLUS $19 \& 20$ )

House 5 was dug into compact gravel at the eastern extremity of the main group, and measured about $10 \mathrm{~m}$ in diameter at its widest point. Truncation had been quite severe and the greatest depth remaining of the ditch was $0.5 \mathrm{~m}$, although this was fairly consistent. The interior of the house was much less clearly segmented than was the case with the other buildings. This may be due to a reconstruction of the building as is suggested below. Of the 35 post-holes, small pits, or depressions in the interior, nine could be seen to form a regular arc $5.5 \mathrm{~m}$ diameter for 270 degrees of the circle. These are illustrated below together with a possible central post-

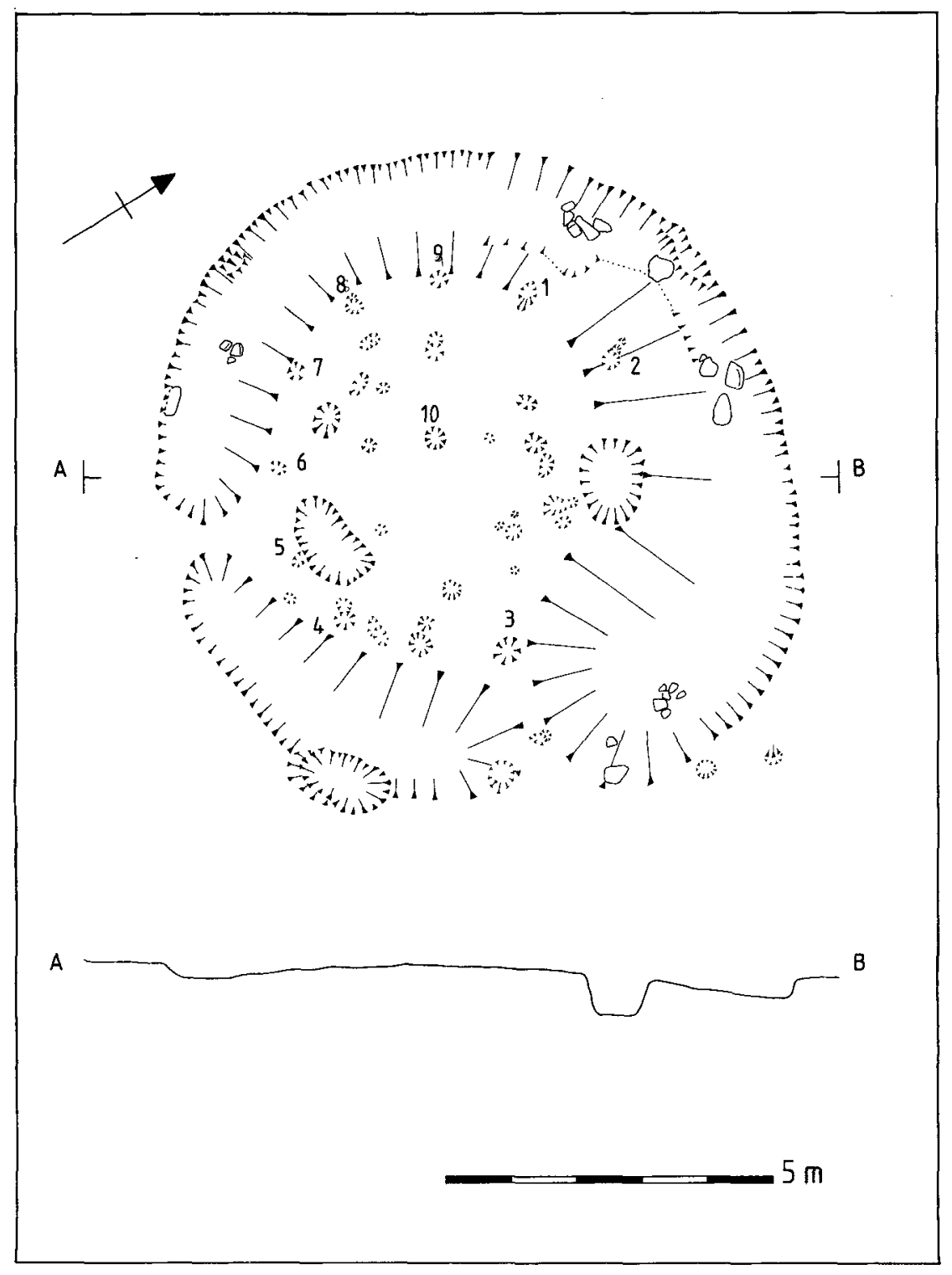

Ilius 19 House 5: excavated plan and profile 


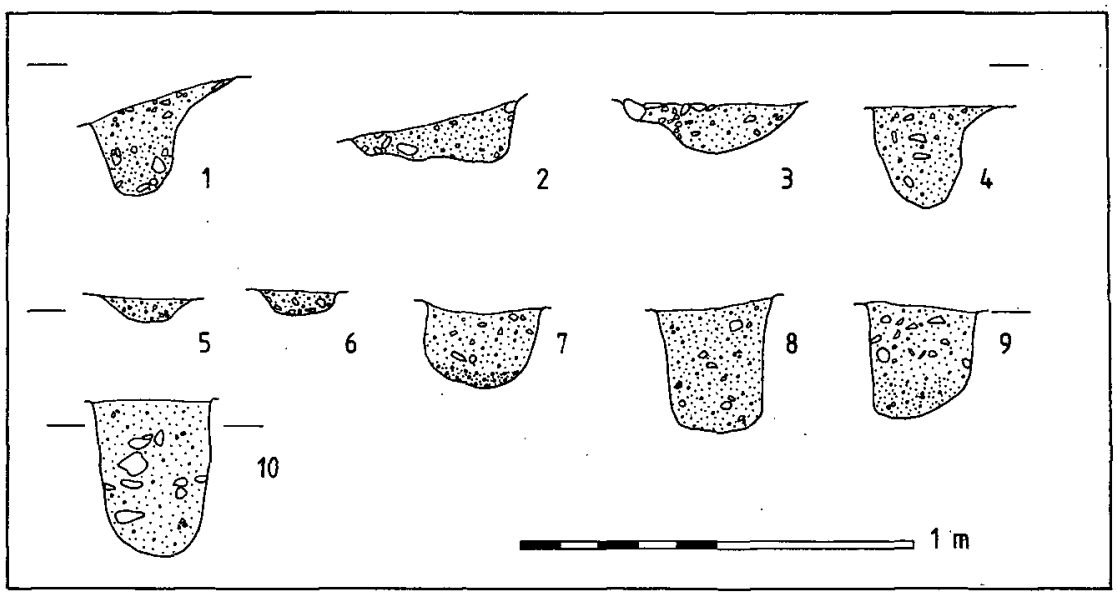

ILLus 20 House 5: structural post-hole sections

hole $(5 / 10)$. The remaining post-holes could not be convincingly interpreted, though they may have formed a secondary arc as is suggested for House 3 or an earlier alignment facing south-east as has been suggested for House 1. From the density and position of the post-holes it is likely that this building had been rebuilt.

There were two complete breaks in the ditch, the most marked being that facing south-east. To the east of this the ditch terminal was enlarged and the upper part of this fill of the ditch was coarse and unconsolidated, resembling modern ploughsoil, and contained many small fragments of limestone. A barbed and tanged arrowhead was found in this layer.

There were two pits in the interior of the house, cut into the north and south edges of the central area, and a third that protruded beyond the southerly outer edges of the ditch.

Finds from this house included four quernstone fragments, one polishing stone, two small stones with deeply worked hollows, possibly used as door pivots, and one quartz chip. A soil sample from the basal fill of the ring-ditch on the west produced two seeds of barley, three of oats, four seeds of fat hen, two of chickweed and one each of knotgrass and redshank. A sample of charcoal from a pit associated with the house was submitted for a radiocarbon determination (GU-1472: 791-414 cal BC).

\section{HOUSE 6 (ILLUS $21 \& 22$ )}

The largest and best preserved of the group, this house had an average diameter of $13 \mathrm{~m}$ and stood at a distance of about $100 \mathrm{~m}$ to the north-east of House 5. Before excavation it was visible only as a roughly circular hollow and was not obviously another house site. Topsoil stripping revealed a disc-shaped area of dark loamy soil cut into a subsoil of loose, coarse gravel banded with clean yellow sand. Excavation showed that the loamy layer was only $0.1 \mathrm{~m}$ deep in the centre, but that the penannular ditch of the house was in some places as much as $1.8 \mathrm{~m}$ deep.

The shape of the house was noticeably polygonal rather than circular, comprising six almost straight sections. The strata of the subsoil were such that the coarse gravel on the surface gave way to clean yellow sand at an average depth of $0.3 \mathrm{~m}$. This meant that erosion in the ditch was severe, both in prehistory and during excavation. This also had the effect of making the outer side of the ditch not truly vertical.

A ledge up to $0.75 \mathrm{~m}$ wide ran intermittently around the perimeter of the ditch at a depth of about $0.3 \mathrm{~m}$ from the present subsoil surface. In many places carbonized twigs rested upon it, embedded in burnt clayey soil. A large quantity of carbonized twigs was also noted resting in the base of the ditch close to the near-vertical face and clinging to the side of the ditch. In general the twigs were $10-20 \mathrm{~mm}$ thick but with the 


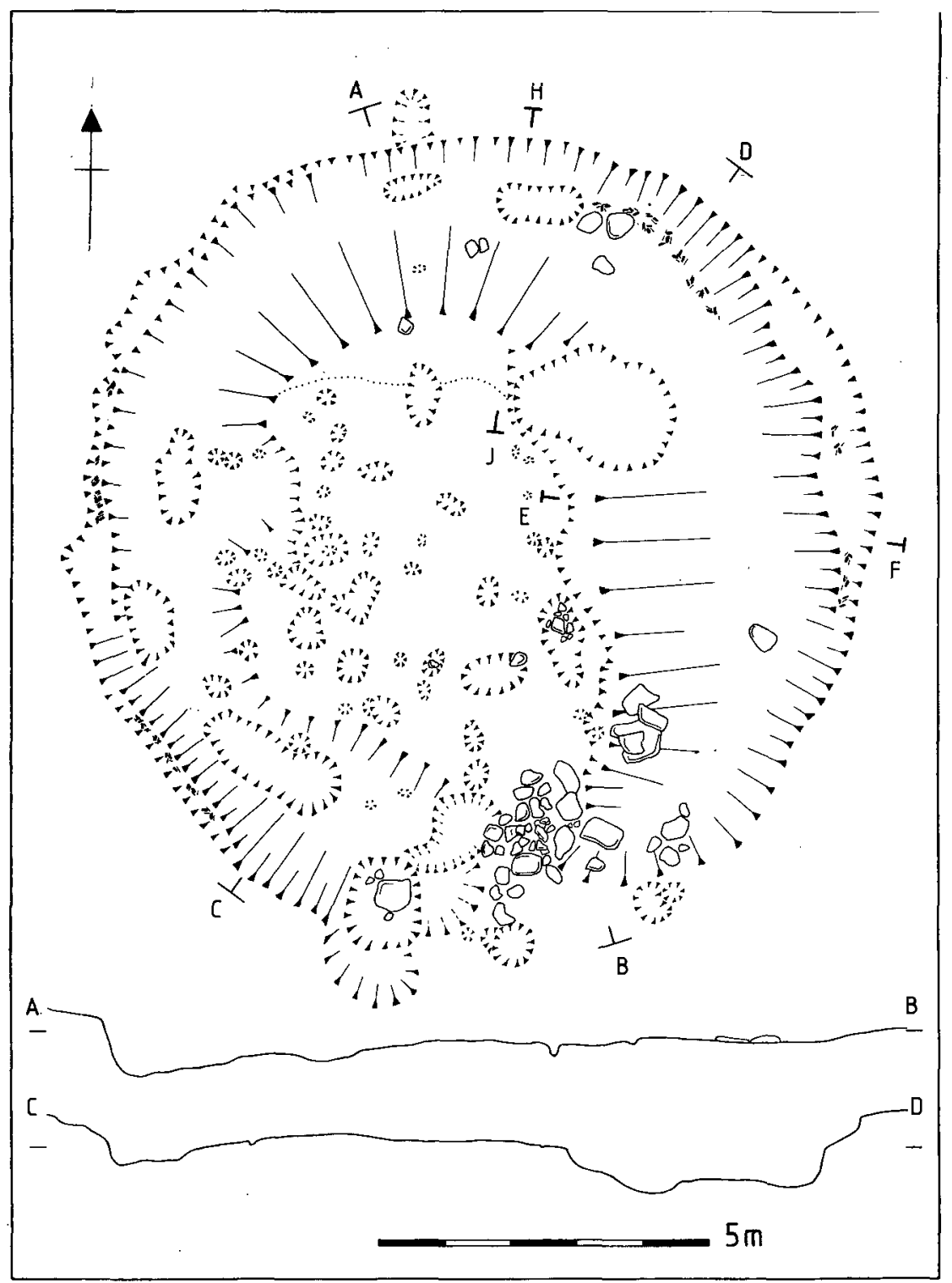

ILLus 21 House 6: excavated plan and profiles

occasional thicker branch of about 50-70 mm thickness. They would appear to be the remains of wattle walling similar in function to that found in House 5. A similar deposit of burnt clay and twigs was found slumped on paving at the north of the house. Charcoal samples were taken from both deposits for radiocarbon determinations (GU-1468: 788-414 cal BC; GU-1471: 761-381 cal BC). Further fragments of burnt twigs, also thought to be part of this burnt wattling, were noted in a pit to the south-west and this layer was sealed by a large stone to a level with the base of the ditch.

The central area of the house was cut by a large number of pits and post-holes, except to the east where 


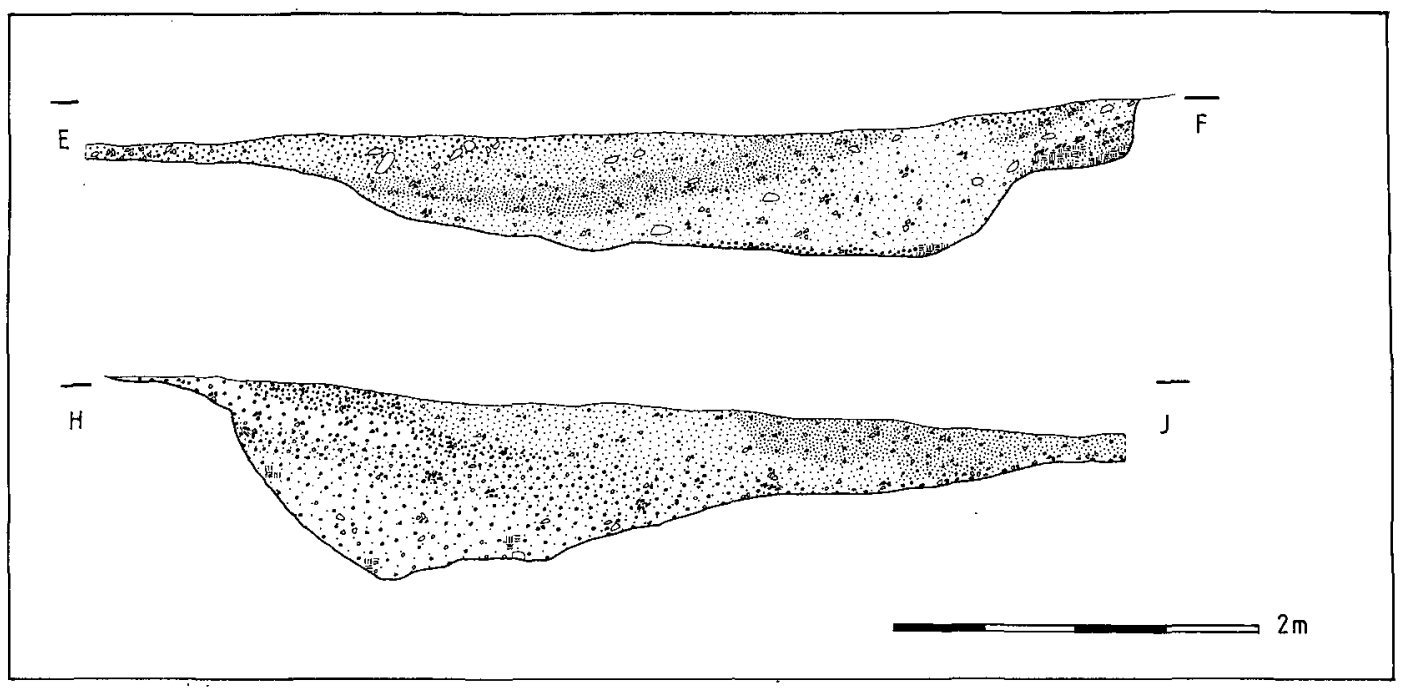

ILLus 22 House 6: ditch sections

the gravel had been eroded, probably because of its loose consistency. From the post-holes remaining, a number of them could be seen to form an arc c $6.5 \mathrm{~m}$ wide on the inner lip of the ditch. Two pairs flanked a paved area to the south between the ditch termini. Two more substantial post-holes were cut on either side of the paved area on the line of the outer edge of the ditch, pairing with the four mentioned above. From the density of post-holes both in the entrance and on the inner edge of the ditch it would seem likely that the timbers in this house were replaced at least once in its life. The ledge observed extending from the outer edge of the ditch may have been a remnant of this earlier building. It is unlikely to have acted as a support for the roof posts as it would only allow restricted headroom.

A deposit of clay capped with large flat stones rested against the side of the ditch to the north-east of the east terminal. The paving covered the area between the two ditch termini and was largely composed of sandstone slabs, five of which were remains of saddle querns, and included part of a piece of sandstone with a deeply worked hollow lying face down. A further quern fragment was found in the base of the ditch at the north. A pit inside the ditch in the south-west produced 31 grains of barley, five of bristle oat, two of wheat and four seeds of runch (wild radish) and one of charlock. A sample taken from the pit with possible wattling in the south-west contained ten grains of wheat and one seed each of fumitory and ivy-leaved speedwell.

\section{OTHER STRUCTURES (ILLUS 23-5)}

There were other types of structure present; immediately recognizable from the outset of the excavation were the crescent-shaped hollows and, becoming apparent during the excavation, rectangular arrangements of postholes. All these features will be more fully discussed later in the report. In addition there were many 'stray' pits and post-holes.

Three crescent-shaped hollows were excavated and they may represent the remains of ploughed-out houses originally similar in form to Houses 1-6 (illus 23). However, if the crescents are the remains of ringditches their dimensions would make them substantially larger than the other houses. Within the area of Structure 9, a later six-post structure, E, was inserted, identified by its deeper post-holes.

Structure 7 ( $\mathrm{C} 1$ in illus $10 \& 23$ ) was cut into an area of silt, and had a fill of dark silty loam very similar to the fills of the house ditches. It contained much charcoal and a basal layer of grey, clayey material. The inside of the arc faced almost due south and on this side there were also a number of post-holes, which 


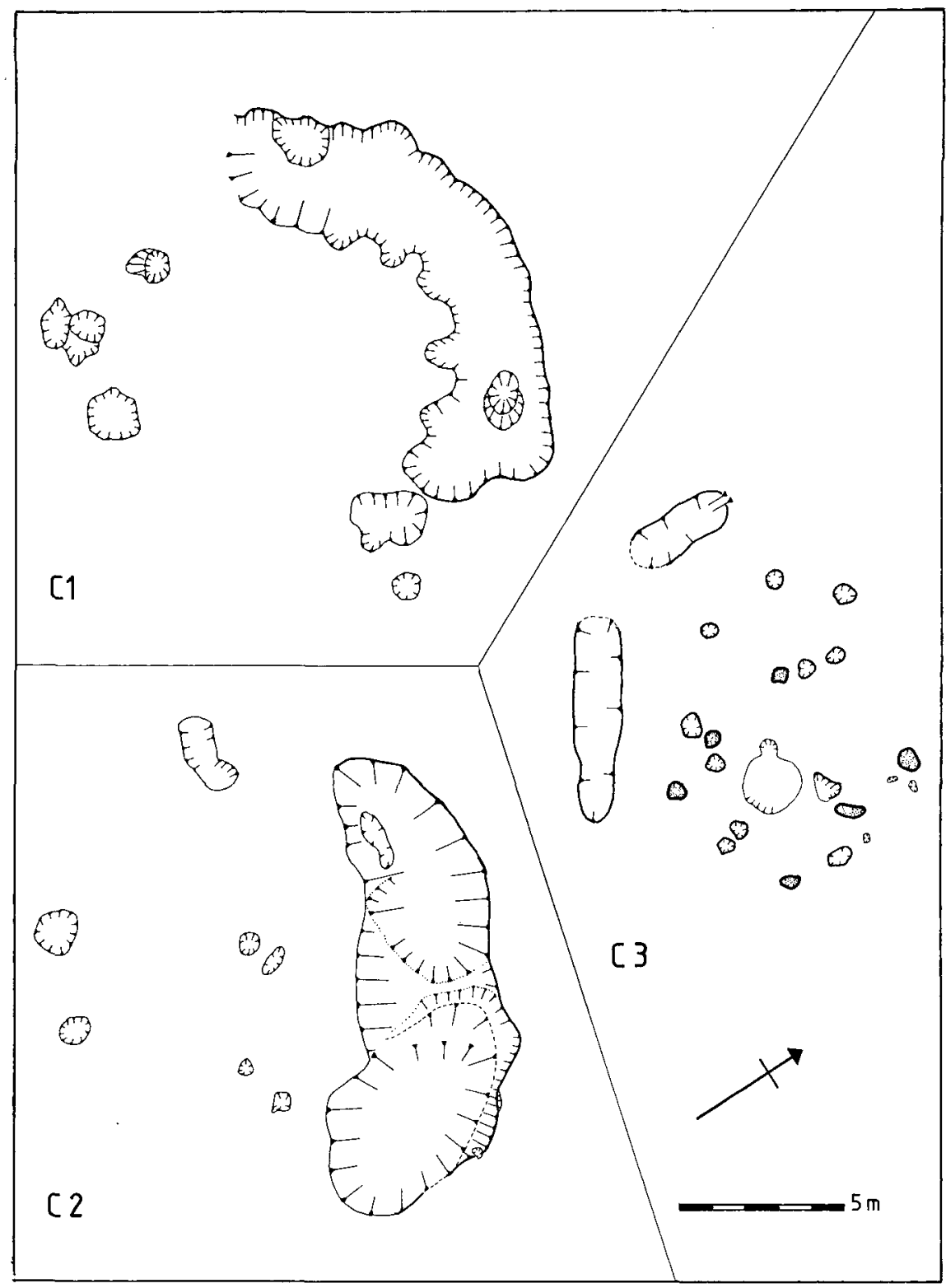

ILLus 23 Comparative plans of the three crescent-shaped hollows; shaded post-holes mark the position of Structure E

were often badly obscured by the naturally deposited silt into which they were cut. A radiocarbon sample was taken from within the crescent (GU-1467: 765-403 cal вC).

Structure 8 (C2 in illus $10 \& 23$ ), to the south-west of House 2, also faced south and had several pits and post-holes to its southern side. In form it was slightly different from Structure 7, being composed of two shallow depressions connected by a causeway that was below the present subsoil surface. Each had a small area of rough cobbling in its base. 
Structure 9 (C3 in illus $10 \& 23$ ) was much shallower, having a maximum depth of $0.1 \mathrm{~m}$, although it was also an arc. If the deeper post-holes of Structure $\mathrm{E}$ are removed from the plan, a ring of posts some $8 \mathrm{~m}$ in diameter can be recognized. The central pit in this feature may have related to either Structure 9 or Structure E. A sample from this contained five grains of barley, one of oat, nine seeds of chickweed, three of meadowgrass, two of spurry, one of fat hen and one of cocksfoot.

Eight rectangular structures composed of settings of post-holes were also identified (illus 24). These ranged from a five-poster (A), through six-posters (D, E, F, G) to seven-posters (B, C, H). G and $\mathrm{H}$ were at first thought to represent one structure, but a slight shift in alignment, and a fairly large break between two

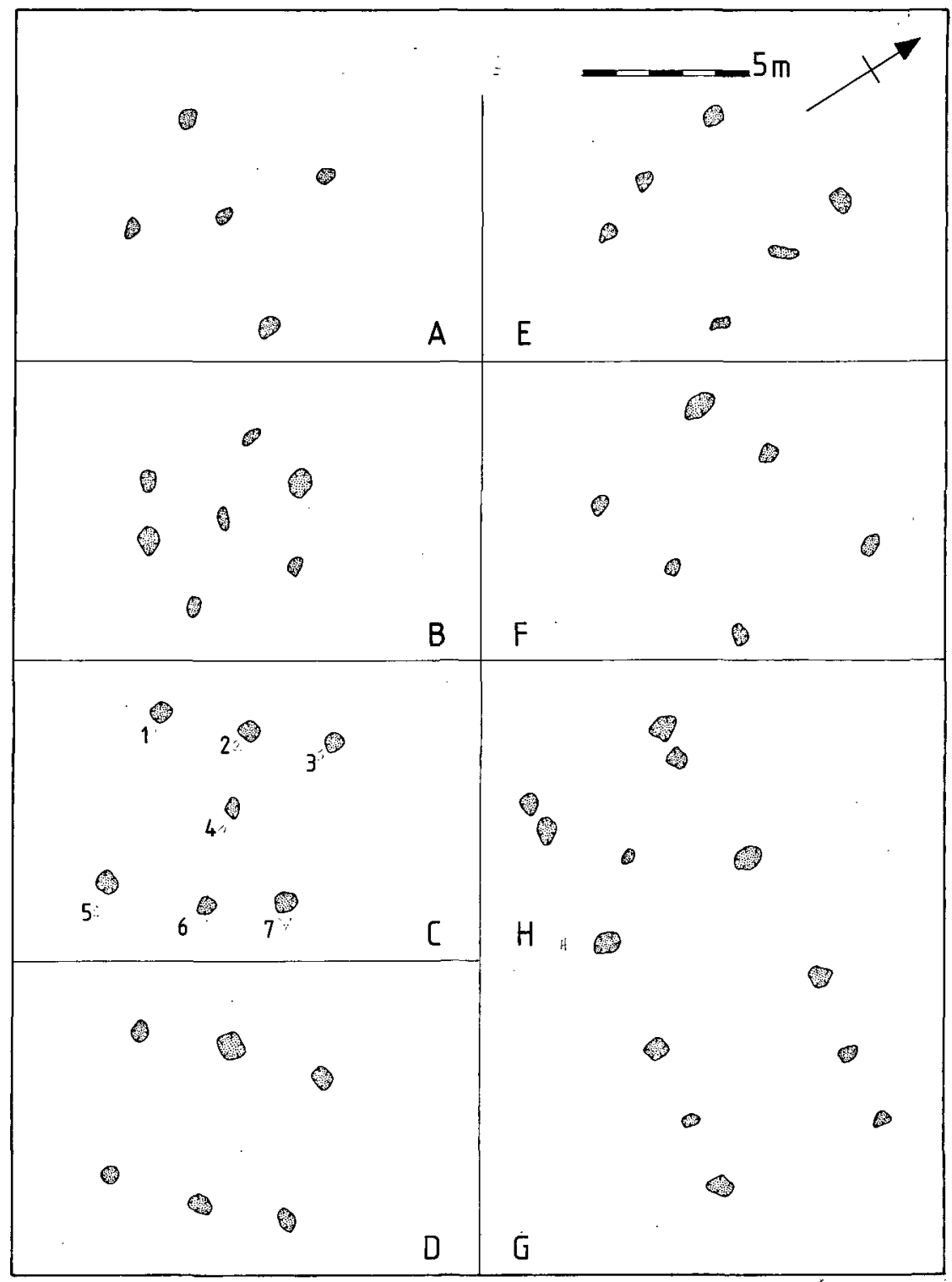

ILLus 24 Comparative plan of rectangular Structures A-H 


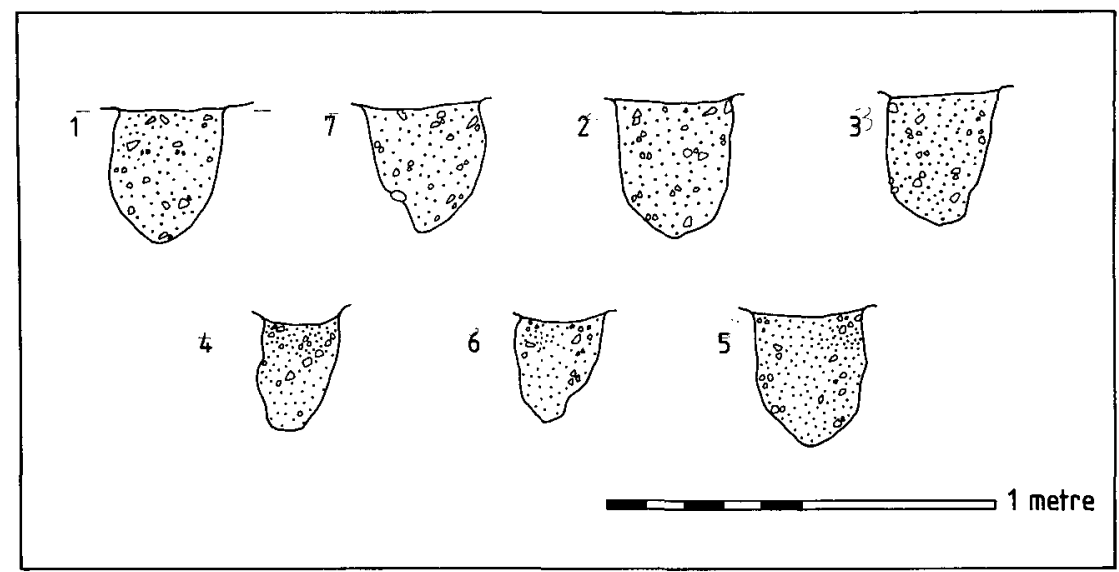

ILLus 25 Sections of the post-holes in Structure C

post-holes on the east side, suggested two smaller buildings similar to others found on the site. In illus 24, $\mathrm{G}$ and $\mathrm{H}$ are drawn together, to demonstrate their proximity; $\mathrm{G}$, and most of $\mathrm{H}$, were obscured by what appeared to be a fairly recent ploughsoil filling a shallow north/south aligned depression. The most modern ploughing had not penetrated this layer, which probably dates to the first modern ploughing of the site when the more marked irregularities in the land would have been levelled. There were several other examples of this type of buried ploughsoil on the site, for example in House 5 as has already been described. The average dimensions of the six-posters were $4.5 \mathrm{~m}$ by $5.5 \mathrm{~m}$; this is true of at least two adjacent sides in every case. $\mathrm{G}$ and $D$ are of these dimensions almost exactly, although $G$ is otherwise abnormal in having the middle postholes along the short sides. $\mathrm{E}$ and $\mathrm{F}$ were not so symmetrical, but both had the middle posts on the long sides.

Of the seven-post structures, $\mathrm{H}$ measured $5 \mathrm{~m}$ square, $\mathrm{C} 5 \mathrm{~m}$ by $5.5 \mathrm{~m}$, and $\mathrm{B}$, although more hexagonal than rectangular in shape, had an east/west dimension of $5 \mathrm{~m}$. The five-poster A was $4.5 \mathrm{~m}$ square except for the position of the south-east post-hole, and was similar to the southerly five posts of $\mathrm{H}$. In short, all these structures, if the plans were superimposed, would have covered similar ground areas. The post-holes in all the structures were on average $0.15 \mathrm{~m}-0.2 \mathrm{~m}$ in diameter with a depth of $0.2 \mathrm{~m}$ and a fill of dark brown gravelly loam. Only occasionally was a post-pipe discernible (illus 25 ).

Large quantities (100t) of wheat grains were recovered from Structure D as well as 15 grains of barley and one of oat. A single grain of wheat together with a seed of dovesfoot cranesbill were recovered from Structure $\mathrm{H}$ and single grains of wheat and barley were found in possible stake-holes near Structure F.

\section{OTHER FEATURES}

Other features, which will not be described in detail, consist of groups of pits, mainly occupying five areas: to the south of House 1, to the south of House 2 (grouped in both cases to the south-west of a crescent-shaped hollow), to the west of House 4, and (already described) west and south of House 5. Those to the west of House 4 can be described simply as shallow depressions filled with a dark brown stone-free silty loam. The fill did not respond positively to phosphate testing. The other groups of pits were similar to those found in the house interiors, and were usually flat bottomed, straight sides, and often had a high charcoal content. Generally the interior house pits were deeper than their surrounding ring-ditches, so it is possible that a group of 'stray' pits may represent the remains of a house where the penannular ditch has eroded away for one reason or another. However, this is unlikely to have happened where the pits are in proximity to substantial house remains, such as to the south of House 5, unless they are perhaps the remains of an earlier house site. The group of features outside House 6 were all due to modern disturbance such as bush, tree, or animal holes and had loose modern fills. 


\section{RADIOCARBON DATES}

Charcoal samples were submitted from five locations for radiocarbon dating. They have been calibrated using the OxCal calibration programme based on the work of Stuiver \& Becker (1993) and are quoted with 95\% confidence. Identifications were carried out by Carole Keepax. The context of a further sample (GU$1317)$ is uncertain and has been omitted. The calibrated range $(775-413 \mathrm{BC})$ in no way alters the spread of dates.

TABLE 2

Lab. No. Sample/material

GU-1466 Pit in centre of House 1. Hazel, alder, ?Prunus sp. (some twiggy), Leguminosae twig. (CCI 50).

Uncalibrated determination Calibrated Date

$\begin{array}{ll}2465+60 \text { вР } & 766-408 \text { вС } \\ \delta 13 \mathrm{C}:- & \\ 25.3 \% & \\ 2450+60 \text { вР } & 765-403 \text { вС } \\ \delta 13 \mathrm{C}:- & \\ 25.5 \% & \\ 2495+60 \text { вР } & 788-414 \text { вС } \\ \delta 13 \mathrm{C}:- & \\ 24.7 \% & \\ 2400+60 \text { вР } & 764-381 \mathrm{BC} \\ \delta 13 \mathrm{C}:- & \\ 24.3 \% & \\ 2500+55 \text { вР } & \\ \delta 13 \mathrm{C}:- & 791-414 \mathrm{BC} \\ 24.7 \% & \\ & \end{array}$

\section{ARTEFACTS}

The finds from the excavation are in the McManus Galleries, Dundee. Catalogues of the stone and seed finds are listed in the archive. Confusion has crept into the finds record since the excavation and it has not been possible to provide more than a brief summary of what was found in each house:

House 1, 31 finds, comprising three flint flakes, three chert flakes, three fragments of burnt bone, one stone disc fragment, 15 quernstone fragments, one rubbing stone, three smoothed stones, one polished stone, one burnt clay/stone fragment.

House 2, nine finds comprising one flint/chert flake, one complete stone with deeply worked hollow, five quern fragments, two smoothed stones.

House 3, five finds comprising one possible whetstone, two fragments of a stone with deeply worked hollows, one quernstone and one holed slab.

House 4, 39 finds comprising one polished axe fragment and one pot sherd from the topsoil, two bone fragments, one stone disc, one stone blade, one stone weight, one hammerstone, one polished stone, 20 quernstone fragments, seven stones with smoothed surfaces.

House 5, 13 finds comprising one barbed and tanged arrowhead, one small worked flint and one glass bead (thought to be surface finds), four quernstone fragments, one quartz chip, one hammerstone, two possible stone door pivots and one stone with a smoothed surface.

House 6,13 finds comprising nine quern fragments, three burnt bone deposits and one stone ball.

Only one small sherd of pottery was recovered from the excavation and the majority of finds were worked lithics. Of these the predominant item was quernstones reused as paving on the floors of the houses; various rubbing and polishing stones were also found. No particular pattern of deposition of these stones was evident, and as most of them were broken in antiquity their reuse is more likely to reflect a local scarcity of stone. A few rough stones with deeply worked hollows - almost like the interiors of stone bowls - were also recovered. The few flint flakes and chert fragments found suggest that tools were reused or removed 
wherever possible and it is likely that the majority of the Douglasmuir inhabitants used wood and bone tools that have not survived. The majority of finds (mainly the querns, etc) were reported on soon after the excavation by Hilary Cool; her report is in the archive. A further report on three of the stone tools was commissioned from the Artefact Research Unit of the National Museums of Scotland by Historic Scotland in 1994.

\section{LITHIC FINDS}

\section{Alan Saville}

The lithic finds include three items which are illustrated and warrant separate description:

1 Stone blade (archive cat. no. 18); from pit RA 10 in House 4 (illus 26). Tabular, narrow piece of grey-brown sandstone carefully fashioned into a blade-like tool. The trapezoidal planform is the result of shaping and grinding on all edges. The edges at the sides and the base are ground flat, either perpendicular or slightly at an angle to the flat faces. There is a slight notch in the butt edge which is also ground. The cutting edge is bevelled, with bifacial grinding giving an acute-angled edge. The dimensions are: length $78 \mathrm{~mm}$; maximum breadth $63 \mathrm{~mm}$; and thickness $10 \mathrm{~mm}$; the weight is $59 \mathrm{~g}$. This implement shows every sign of having been well used.

Parallels for this tool have proved elusive. It does bear a resemblance in morphology and working to one of the so-called 'Riverford' clubs from Ireland (Mahr 1937, fig 5, right), except that it is about onequarter the size. There are resemblances also to the type of stone knife with bevelled cutting edge, two examples of which have been found at Skara Brae (Childe 1931, pl LII.2; Clarke 1976, fig 5.2). The blade would presumably have been hafted, and could have served a variety of cutting, scraping, and chopping functions.

2 Stone disc (archive cat. no. 19); from pit RA 10 in House 4 (illus 26). Flat, sub-circular disc of grey-brown shaly mudstone, slightly damaged. Shaped by chipping and grinding of the edge, which is quite undulating and irregular. One flat face is much smoother than the other and has some linear striations, but neither face appears to have been deliberately ground. The maximum dimension is $69 \mathrm{~mm}$; maximum thickness $8 \mathrm{~mm}$; and the weight is $47 \mathrm{~g}$.

Stone discs of various kinds are relatively common finds on Iron Age and later sites in Scotland (eg Watkins 1980, 157 and fig.20). This example would appear to fit the rather generalized category of 'type c' stone discs as defined by Henshall (in Taylor 1982, 235). The function of these smaller discs is unknown and there is debate as to whether the edge grinding relates to deliberate shaping or is acquired by use.

3 Stone axehead fragment (archive cat. no. 12); from the upper infill of the ring ditch of House 4 (illus 26). This is the blade end of a polished stone axehead, which has snapped transversely, almost exactly at right angles to the long axis. The remaining portion is polished all over. The colour is pale grey and the rock is fine-grained, probably volcanic, but of a non-exceptional type which would require a thin-section to be more specific. The dimensions are: length $115 \mathrm{~mm}$; maximum breadth $90 \mathrm{~mm}$; breadth at the cutting edge $85 \mathrm{~mm}$; thickness $43 \mathrm{~mm}$; the weight is $653 \mathrm{~g}$.

This is part of what has been a very substantial axehead. Comparison with examples in the collection of the National Museums of Scotland indicates the axehead, when complete, would have been in the region of $240-290 \mathrm{~mm}$ in length. This would place it towards the large end of the size spectrum for Scottish stone axeheads, and may suggest the original axehead was for ceremonial rather than practical use.

After breakage there has been flaking from the break-edge over both faces and there is major abrasion along one lateral edge and lesser abrasion on the other edge and on one face, but no abrasion on the breakedge itself. Thus the abrasion may or may not have occurred after breakage; an axehead of comparable size 

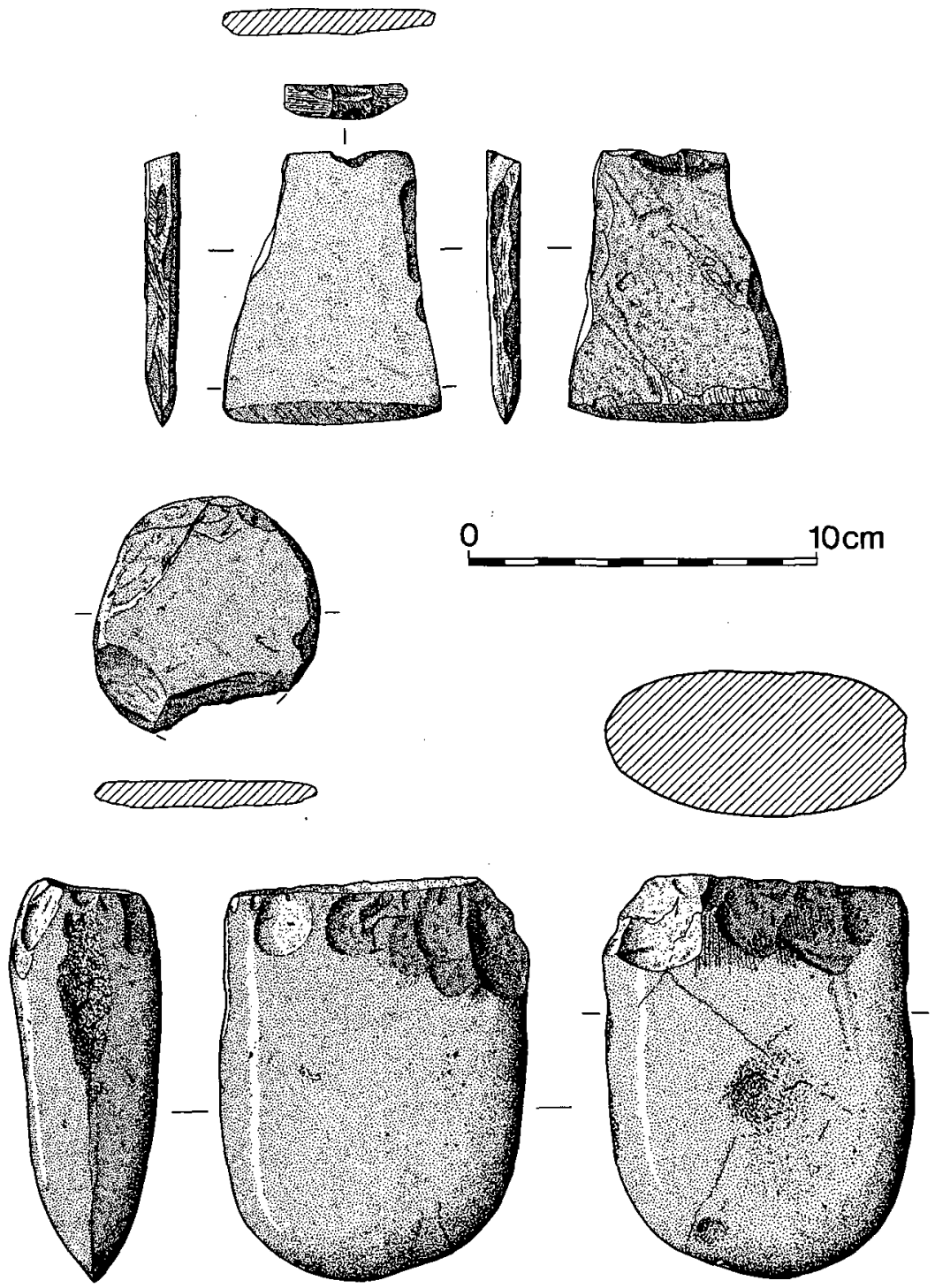

ILLus 26 Stone artefacts: blade (18); disc (19); axehead (12). Scale 1:2 (Drawn by Alan Braby)

from near Jedburgh is intact, despite use as a hammer and anvil (NMS cat. no.: AF 890; Black 1894, fig 4). The flaking suggests the Douglasmuir fragment has been used in its present form, possibly again as an axehead but also perhaps as a hammer.

Neolithic axeheads or fragments thereof are not uncommon finds on later settlements, including those of Iron Age date (eg Piggott 1948, 215 and fig 11.5), where their presence could often be residual and purely coincidental. In the present instance it must remain a possibility that reuse after breakage could be contemporary with the settlement activity, indicating Iron Age exploitation of a chance acquisition. 


\title{
DISCUSSION AND INTERPRETATION
}

\author{
Jill Kendrick
}

\section{RECONSTRUCTION OF A DOUGLASMUIR HOUSE}

Much thought has been given to the reconstruction of a Douglasmuir house presented here (illus 27). There is little doubt that the penannular ditch is different in function from the drip-gully or ring-groove seen on other round timber houses such as West Plean, Stirlingshire (Steer 1956), and, whilst being an intrinsic constructional element, was probably an internal feature.

In this reconstruction, the main roof rafters are supported on a low turf wall outside the ditch, since it is felt that the small ring-beam posts would not be sufficient to bear the weight of the roof by themselves. Hence the ground is the main load-bearer. With an optimum roof pitch of 45 degrees the ring beam would support the rafters half-way along their length. The wide, low turf wall would provide a basis for the porch, as in House 1 where the porch post-holes were positioned about $2 \mathrm{~m}$ beyond the outer edge of the ditch terminals. This arrangement would provide a very stable structure, affording a substantial and well-insulated internal area of up to $132 \mathrm{~m} \mathrm{sq}$, and the internal ditch would allow headroom at the perimeter of the house. Paving would alleviate any problems of waterlogging in the base of the ditch, although in such a quick draining subsoil these would be minimal. Greater than the problem of drainage would be that of erosion, especially in House 6 where the subsoil was largely sand. The near vertical ditch side would be most vulnerable. It is postulated that to relieve this a wattle screen was placed against the side of the house, probably reaching from the lowest point of the ditch to the roof. Excavated evidence can be seen in House 4, where the vertical side of the ditch showed upright stake impressions at c $0.2 \mathrm{~m}$ intervals. This spacing is ideal for the uprights of a wattle fence. In House 6 there was a great number of carbonised twigs and small branches in the base of the ditch near its perimeter, and resting on ledges near the top of the ditch, often surrounded by a clayey soil burnt to a bright orange colour. The twigs have been largely identified as hazel, willow, and birch which are still most commonly used in the construction of wattling and hurdling. In the reconstruction the wattling is sealed with daub.

The inclusion of a second storey is speculative, but, with an apex height of about $6 \mathrm{~m}$ and a total volume of approximately $300 \mathrm{cu} \mathrm{m}$, it is a reasonable possibility. This would cause no constructional problems since it would rest on the ring beam, and might have helped to reinforce it.

The porch may have extended through the thick outer wall, as can be seen in House 1 where the porch post-holes are situated at a distance of a ditch width from the perimeter. This would provide a long porch using the sides of the walls for support, which would be well insulated and easily constructed. It has been noted that in Houses 1, 2, and 4, several post-holes were situated inside the ditch by the entrance. It could be that these supported a screen that would provide protection from cold winds when the door of the house was opened. A central post, only occurring in Houses 4 and 5, would be unnecessary in this type of construction but this may be a case of over-caution. It cannot be assumed that there was complete confidence in the building design.

Other post-holes in the interior cannot be assigned functions with any confidence. There is a suggestion of an inner ring of posts for Houses 1, 3, 5 and possibly 6. Some of the houses appeared to have internal divisions linked to the scoops in the ditch. Some internal structures such as looms would require only a pair of posts which may confuse the pattern of large numbers of posts in one structure. Because these cannot be positively identified it is not possible to reconstruct internal divisions or attempt to suggest spatial variants within the houses. It is possible that the variants between the houses do reflect some functional difference. For example, the extra paving in House 1 


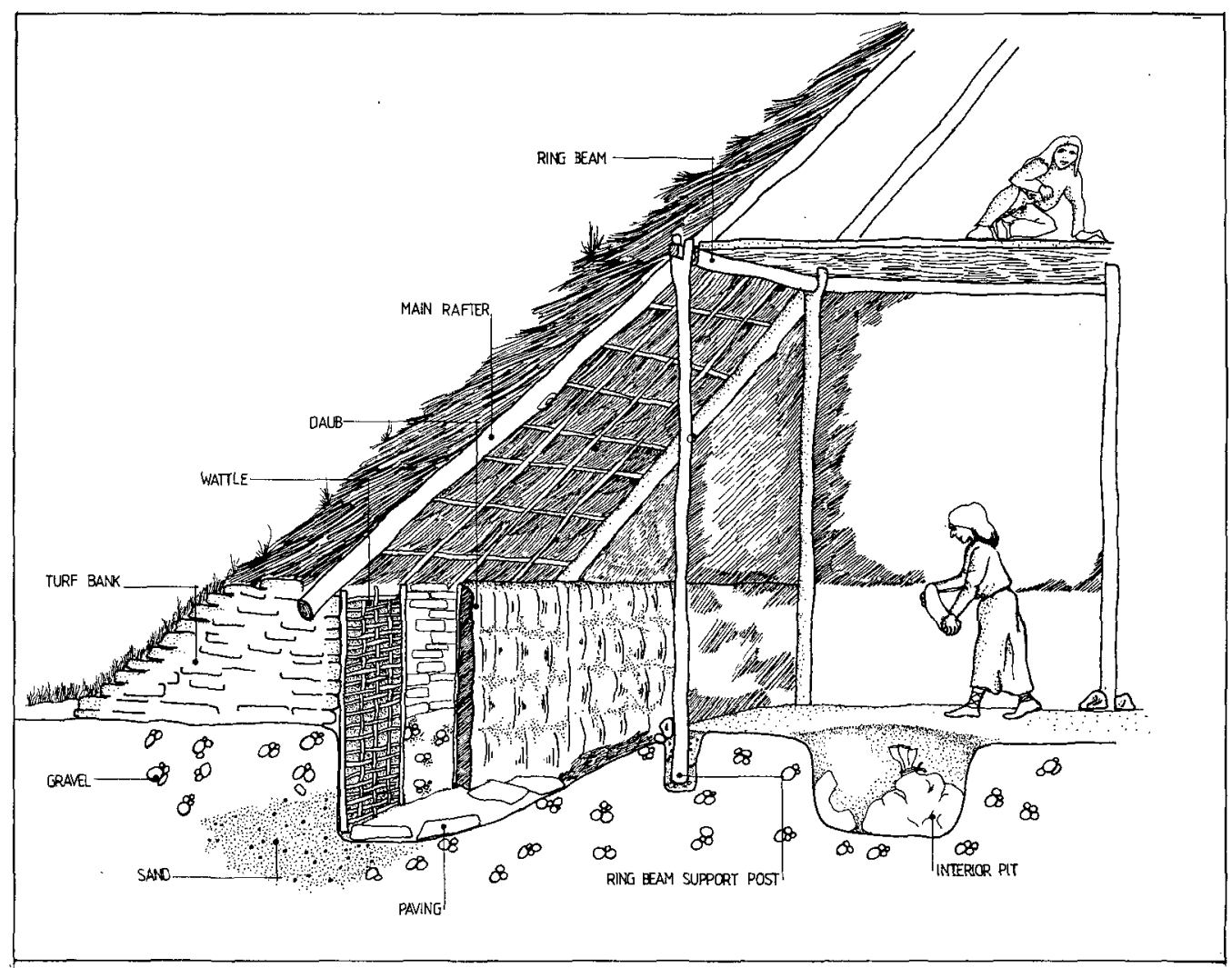

ILLus 27 Reconstruction of a Douglasmuir house (Drawn by Jill Kendrick)

may show that animals were stabled here. Unfortunately the poor survival of finds other than lithics and the degraded nature of the soils makes such discussion pure speculation. The distribution of quern and other worked stones within the paving was random and, since many of these stones were fragmentary, their distribution is thought to reflect the dearth of local stone rather than a ritual positioning.

A reconstruction based on the excavated evidence was produced by Architecture Students studying under Bruce Walker at Duncan of Jordanstone College, Dundee. The physical reconstruction of part of the house is displayed in the McManus Galleries, Dundee.

\section{PARALLELS}

From the extant information on excavated examples of prehistoric round houses, there are several that can be compared with the Douglasmuir type on the criterion of having a broad penannular ditch, or an arrangement of features that allows for a similar reconstruction to that postulated for Douglasmuir.

Hut 1 on Braidwood Fort, Midlothian (Stevenson 1949), had a broad, scooped ditch, with a ring of post-holes on its inner lip and a characteristic porch structure of post-holes paired across 
the ditch. The ditch was much shallower than those at Douglasmuir, but was dug into bedrock. The dimensions were smaller with a diameter of about $8 \mathrm{~m}$. Hownam Rings, Roxburghshire (Piggott 1948), and Green Craig, Fife (Bersu 1948), both had the remains of a bank or wall of stones or turf surrounding an area of paving, post-holes, or paving and post-holes. The projected diameter of the house at both these sites was about $13 \mathrm{~m}$. It is possible that the timbers of a roof rested on these walls as is suggested in the Douglasmuir reconstruction, and that due to the more substantial wall height an internal ditch to provide headroom was unnecessary. These examples seem to be later in date than Douglasmuir, suggesting that the building tradition had a long life, especially in upland areas. In stone-rich areas it may have remained in a more substantial form.

The radiocarbon dates obtained from Douglasmuir are similar to those obtained from an early phase of Dryburn Bridge, a palisaded settlement in East Lothian ( $\mathrm{J}$ Triscott, pers comm) represented by a palisade and yielding an assemblage of finds similar to that from Douglasmuir. One of the later houses at Dryburn, House 7, resembled the Douglasmuir type closely, being about $8 \mathrm{~m}$ in diameter, with a penannular ditch about $1.5 \mathrm{~m}$ broad, and with a south-facing entrance and external porch structure. Dryburn also had several six-post structures similar in size to those at Douglasmuir.

There is little information north of the Forth with which to define the limit of the area within which this type of house occurs; there are few excavated examples and unexcavated houses do not provide enough data. There are many examples of ring-ditch cropmarks in the Lunan Valley, amongst which 26 examples, either singly or in groups, are penannular, appear to have substantially wide ditches, and are unenclosed. Hence there seems to have been a building tradition of broad penannular ditched houses shared by at least Lothian and Angus, and dating to the Iron Age. Other examples that have a narrow trench cannot be said to belong to this tradition although some have a similar post-hole arrangement, for example at West Plean, Stirlingshire (Steer 1956). The narrow trench may have supported a low fence or wall that carried the roof rafters up to the ring beam, or the main rafters may have rested on the ground beyond the wall, providing the extra stability of the postulated Douglasmuir arrangement.

The scooped nature of most of the ditches of the houses at Douglasmuir has already been noted, and allows several interpretations. It could be an effect of the building method in which the ditch was dug in sections after the low external wall had been erected. Alternatively the small 'causeway' between the scoops may represent divisions, each resulting bay perhaps being assigned a separate function. In Houses 2 and 4, post-holes were cut into the centre of some of the causeways suggesting that the bays may have been more strongly divided with screens. In some cases the bays correspond roughly with the ring-beam post-holes. An interesting parallel is evident in the northern Scottish wheelhouse sites such as Calf of Eday, Orkney (Calder 1939) and A' Cheardach Mhor, South Uist (Young \& Richardson 1960), and some brochs, in which the stone wall encloses a ring-shaped bayed area which in turn surrounds an open central area. In the case of Calf of Eday, some of the bays are divided by edge-set stones, but on other examples, by quite substantial short walls. At $\mathrm{Bu}$ Broch (Hedges 1987) there is a similar arrangement of an outer ring surrounding a central area which is also bayed and partially paved. Obviously the internal arrangements of these stone dwellings are not determined by the constructional requirements of a ring beam as in a timber house, but, nevertheless, the building is divided in a similar way, possibly reflecting an influence of timber building traditions of the Douglasmuir type.

The ditch in House 6 is remarkably deep, being at its deepest point some $1.8 \mathrm{~m}$ from the present ground surface, as has already been noted. This was not simply due to limited truncation, although this contributed somewhat to the greater preservation in House 4. This ditch may have had a more distinct purpose than those of Houses 1-5, whilst still being within the building by the 
nature of the construction method, and following precisely the same building tradition as the rest of the settlement. It is possible that the ditch was partly or completely covered, forming a shallow cellar, and that horizontal timbers rested on the ledge near the top of the ditch. Since the subsoil in the ditch was sand, it would have eroded rapidly if it was completely open, and indeed did suffer this, as evidenced by the eccentric appearance of the central plateau. Treated in this way, the ditch of House 6 is similar in idea to the souterrain, which can also be described as a covered, curved ditch. The curvature on the souterrain can then be seen as, again, a case of the dictated building form of wooden round houses imposed on a stone structure, and could be a direct development from broad penannular ditch houses. In most cases souterrains are associated with timber buildings, and in particular at Newmill, Perthshire (Watkins 1980b), the large, paved and stone-walled souterrain, followed the curvature of a circular timber building, from which it could apparently be entered.

At Dalladies, Kincardineshire (Watkins 1980a), the curved, vertical-sided ditches were reinforced with stone panels or wattle hurdling. The stone panels had post-sockets at either end, and may perhaps represent a transition phase from timber to stone construction. The Dalladies ditches are referred to as 'souterrain-related structures', and may be regarded as a development from deeply ditched round houses to a true souterrain. At least one of the Dalladies ditches (309) appeared to have its entrance within a post-ring house.

\section{SIX-POST STRUCTURES}

Four- and six-post structures have been noted for some time in association with round houses of Iron Age date, at Little Woodbury, Wiltshire (Bersu 1940), Tollard Royal (Wainwright 1968), Rams Hill (Bradley \& Ellison 1975), Staple Howe (Brewster 1963), Myrehead, Stirlingshire (Barclay 1983), and Grimthorpe (Stead 1968) to mention but a few, and they also appeared at Dryburn Bridge. They have been variously interpreted as watch-towers, exposure platforms, granaries, and shrines (Ellison \& Drewett 1976; Bradley 1978). Generally there is little that can be added to recent observations. At Douglasmuir, the large number of cereal grains which were extracted from samples of post-hole fills from Structure D would support the granary interpretation. Carbonized grains have been found only occasionally in such contexts before, notably at Tollard Royal. It is thought that Douglasmuir was not a defensive site, and a watchtower would serve no obvious purpose. The post-holes were in any case not large enough to support such a substantial structure. The presence of grain need not be due to the use of the building as a granary, but it might also have been used for sheltering animals. On-site phosphate testing yielded no positive results, almost certainly because the phosphates had leached through into the gravel subsoil.

\section{CONCLUSIONS}

As an unenclosed farming settlement of the mid first millennium BC, Douglasmuir was indicative of a stable agricultural community without obvious signs of social hierarchy. There is a tendency to consider this as a period of major social instability leading to the construction of major hillforts, but this emphasis on the monumental sites has led to a neglect of the more mundane settlements such as Douglasmuir. However, there is increasing evidence from aerial photography of the density of these undefended sites and recent work (cf Barclay 1993) is beginning to date these sites and to show how widespread they were. Of course, the preservation by carbonization of wattling in House 6 may be interpreted as a cataclysmic end to the settlement, but as roof timbers were not also preserved a more prosaic end is likely. Indeed the wattling sealed beneath a pit in the ring- 
ditch suggests some of this wattling is from an earlier phase of use within the building. The density of post-holes within Houses 1,5 and 6 suggest that these buildings were all rebuilt and, together with the evidence from Structures 7-9, show that the settlement was occupied for some time. The radiocarbon dates cannot be statistically distinguished and therefore only allow this settlement to be broadly dated to the mid first millennium BC.

The carbonized grains and the quernstones show that arable farming was an important element in the structure of this community. The lack of bone preservation means that we cannot know to what extent a mixed economy was practised. The weed seeds and the survival of the buildings suggest the area was totally abandoned, possibly until rig-and-furrow agriculture was introduced in medieval times. Recent analysis has established a framework for this rig-and-furrow development (Pollock 1987) but it is still unclear precisely when this developed.

\section{ACKNOWLEDGEMENTS}

I would like to thank Jean Comrie, Graham Brown, Sharon Dixon, Annette Wight, Steve Cracknell and all the volunteers who assisted with the excavation, especially the longer-term diggers whose skill and cheerfulness were inexhaustible. I would also like to thank J C C Romans, David Habershaw, Adam Welfare, Carole Keepax, Hilary Cool and Bruce Walker for their specialist advice. The excavation was financed by British Gas (1980) and Historic Scotland (formerly $\operatorname{SDD}(\mathrm{AM})$ ). Gordon Barclay was most helpful and encouraging in bringing this report to completion. I am also grateful to the residents of Arbroath and Friockheim who expressed such a keen interest in the site. Alan Saville would like to thank Dr Alec Livingstone for help with the geological identifications and Trevor Cowie for reading and commenting on the text. Gordon Barclay would like to thank Jill Harden for her assistance, RCAHMS (particularly Ms M Brown) for providing rectified aerial photograph plots for the preparation of illus 8 , the Cambridge University Committee for Aerial Photography for permission to publish illustrations 3 and 9, and Angela Townshend for her drawings.

\section{REFERENCES}

Barclay, G J 1983 'The excavation of a settlement of the later Bronze Age and Iron Age at Myrehead, Falkirk District', Glasgow Archaeol J, 10 (1983), 41-71.

Barclay, G J 1993 'The excavation of pit circles at Romancamp Gate, Fochabers, Moray, 1990', Proc Soc Antiq Scot, 123 (1993), 255-68.

Barclay, G J forthcoming 'The Neolithic,' in Edwards, K (ed) Scotland: Environment and Archaeology 8000 BC to $A D 1000$.

Barclay, G J \& Maxwell, G S 1991 'Excavation of a Neolithic long mortuary enclosure within the Roman legionary fortress at Inchtuthil, Perthshire', Proc Soc Antiq Scot, 121 (1991), 27-44.

Barclay, G J, Maxwell, G S, Simpson, I A \& Davidson, D 1995 'The Cleaven Dyke: a Neolithic cursus monument/bank barrow in Tayside Region, Scotland', Antiquity, 69 (1995), 317-26.

Barclay, G J \& Russell-White, C 1993 'Excavations in the ceremonial complex at Balfarg/Balbirnie, Glenrothes, Fife, Proc Soc Antiq Scot, 123 (1993), 43-210.

Bersu, G 1940 'Excavations at Little Woodbury, Wiltshire', Proc Prehist Soc, 6 (1940), 30-111.

Bersu, G 1948 “"Fort” at Scotstarvit Covert, Fife', Proc Soc Antiq Scot, 82 (1947-8), 241-63.

Bersu, G 1948 'Rectangular enclosure on Green Craig, Fife', Proc Soc Antiq Scot, 82 (1947-8), 264 -75.

Black, G F 1894, 'Descriptive catalogue of loan collections of prehistoric and other antiquities from the Shires of Berwick, Roxburgh, and Selkirk' Proc Soc Antiq Scot, 28 (1893-4) 321-42.

Bradley, R 1978 The Prehistoric Settlement of Britain. London. 
Bradley, R \& Ellison, A 1975 Rams Hill: a Bronze Age defended enclosure and its Landscape. Oxford (= BAR Brit Ser, 19).

Brewster 1963 The Excavation of Staple Howe. York.

Calder, C S T 1939 'Excavation of Iron Age dwellings on the Calf of Eday in Orkney', Proc Soc Antiq Scot, 73 (1938-9), 167-85.

Childe, V G 1931: Skara Brae: a Pictish village in Orkney. London.

Clarke, D V 1976. The Neolithic village at Skara Brae, Orkney: 1972-73 excavations, an interim report. Edinburgh.

Cowie, T G 1993 'A survey of the Neolithic pottery of eastern and central Scotland', Proc Soc Antiq Scot, 123 (1993), 13-41.

Dennell, R W 1976 'Prehistoric crop cultivation in Southern England', Antiq J 56 (1976), 11-23.

Ellison, A \& Drewett, P 1976 'Pits and post-holes of the British Early Iron Age: some alternative explanations', Proc Prehist Soc, 87.1 (1976), 183-94.

Goodwin, H 1975 The History of the British Flora. Cambridge.

Harding, D (ed) 1982 Later Prehistory in South-East Scotland. Edinburgh.

Hedges, J W $1987 \mathrm{Bu}$, Gurness and the Brochs of Orkney. Oxford (= BAR Brit Ser, 163).

Hill, P 1982 'Broxmouth Hillfort excavations 1977-78: an interim report', in Harding, D (ed) (1982), $141-88$.

Kendrick, J 1980 Douglasmuir: the Excavations of an Early Iron Age Settlement and a Neolithic Enclosure, 1979-1980: Preliminary Report. Privately circulated paper.

Kendrick, J 1982 'Excavations at Douglasmuir, 1979-80', in Harding, D (ed) (1982), 136-40.

Lethbridge, T C 1952 'Excavations at Kilphedir, S Uist and the problem of the brochs and wheel-houses', Proc Prehist Soc, 18 (1952), 176-93.

Loveday, R \& Petchey, M 1983 'Oblong ditches: a discussion and some new evidence', Aerial Archaol, 8 (1983), 17-24.

Mahr, A 1937 'New aspects and problems in Irish prehistory: Presidential address for 1937', Proc Prehistoric Soc, 3 (1937), 261-436.

Maxwell, G S 1978 'Air photography and the work of the Royal Commission on the Ancient and Historical Monuments of Scotland', Aerial Archaeol, 2 (1978), 37-44.

Pollock, D 1987 'The Lunan Valley Project: medieval rural settlement in Angus', Proc Soc Antiq Scot, 115 (1985), 357-400.

Piggott, C M 1948 'The excavations at Hownam Rings, Roxburghshire', Proc Soc Antiq Scot, 82 (1947-8), 193-225.

Ralston, I B M \& Fairweather, A D 1993 'The Neolithic timber hall at Balbridie, Grampian Region, Scotland: the building, the date, the plant macrofossils', Antiquity, 67 (1993), 313-23.

RCAHMS 1978 The Archaeological Sites and Monuments of the Lunan Valley and Montrose Basin, Angus District, Tayside Region. Edinburgh.

RCAHMS 1994 South-east Perth: an Archaeological Landscape. Edinburgh.

Stead, I M 1968 'An Iron Age Hillfort at Grimthorpe', Proc Prehist Soc, 34 (1968), 148-90.

Steer, K A 1956 'The Early Iron Age homestead at West Plean', Proc Soc Antiq Scot, 99 (1955-6), 227-51.

Stevenson, R B K 1949 'Braidwood Fort, Midlothian: the exploration of two huts', Proc Soc Antiq Scot, 83 (1948-9), 1-11.

Stuiver, M \& Becker, B 1993 'High-precision decadal calibration of the radiocarbon time scale AD 1950-6000 BC', Radiocarbon, 35 (1993), 35-66.

Stuiver, M \& Reimer, P J 1993 'Extended 14C database and revised CALIB radiocarbon dating program', Radiocarbon, 35 (1993), 215-30.

Taylor, D B 1982 'Excavation of a promontory fort, broch and souterrain at Hurly Hawkin, Angus', Proc Soc Antiq Scot, 112 (1982), 215-53.

Tolan, M 1988 Cropmark Pit Circles in Scotland. Unpublished BA dissertation presented to Newcastle Univ.

Triscott, J 1982 'Excavations at Dryburn Bridge, E Lothian', in Harding, D (ed) (1982), 117-24.

Wainwright, G J 1968 'The excavation of a Durotrigian Farmstead near Tollard Royal in Cranbourne Chase', Proc Prehist Soc, 34 (1968), 102-47. 
Watkins, T F 1980a 'Excavation of an Iron Age open settlement at Dalladies, Kincardineshire', Proc Soc Antiq Scot, 110 (1978-80), 122-64.

Watkins, T F 1980b 'Excavation of a settlement and souterrain at Newmill, near Bankfoot, Perthshire', Proc Soc Antiq Scot, 110 (1978-80), 165-208.

Whittle, A, Atkinson, R J C, Chambers, R \& Thomas, N 1992 'Excavations in the Neolithic and Bronze Age complex at Dorchester-on-Thames, Oxfordshire, 1947-1952 and 1981', Proc Prehist Soc, 58 (1992), 143-201.

Young, A \& Richardson, K M 1960 'A Cheardach Mhor, Drimore, S.Uist', Proc Prehist Soc, 24 (1959-60), 135-73.

This paper is published with the aid of a grant from Historic Scotland 